\title{
A propos van de affaire Laurent Timmermans
}

Citation for published version (APA):

Berkvens, A. M. J. A. (1999). A propos van de affaire Laurent Timmermans. LGOG.

https://doi.org/10.26481/spe.19990924lb

Document status and date:

Published: 24/09/1999

DOI:

10.26481/spe.19990924lb

Document Version:

Publisher's PDF, also known as Version of record

\section{Please check the document version of this publication:}

- A submitted manuscript is the version of the article upon submission and before peer-review. There can be important differences between the submitted version and the official published version of record.

People interested in the research are advised to contact the author for the final version of the publication, or visit the DOI to the publisher's website.

- The final author version and the galley proof are versions of the publication after peer review.

- The final published version features the final layout of the paper including the volume, issue and page numbers.

Link to publication

\footnotetext{
General rights rights.

- You may freely distribute the URL identifying the publication in the public portal. please follow below link for the End User Agreement:

www.umlib.nl/taverne-license

Take down policy

If you believe that this document breaches copyright please contact us at:

repository@maastrichtuniversity.nl

providing details and we will investigate your claim.
}

Copyright and moral rights for the publications made accessible in the public portal are retained by the authors and/or other copyright owners and it is a condition of accessing publications that users recognise and abide by the legal requirements associated with these

- Users may download and print one copy of any publication from the public portal for the purpose of private study or research.

- You may not further distribute the material or use it for any profit-making activity or commercial gain

If the publication is distributed under the terms of Article $25 \mathrm{fa}$ of the Dutch Copyright Act, indicated by the "Taverne" license above, 
A PROPOS VAN DE AFFAIRE LAURENT TIMMERMANS 



\section{A PROPOS VAN DE AFFAIRE LAURENT TIMMERMANS}

Enkele beschouwingen over de hervorming van strafrecht en strafprocesrecht in Oostenrijks Opper-Gelre en de Zuidelijke Nederlanden in de tweede helft van de achttiende eeuw

\section{Rede}

uitgesproken bij de aanvaarding van het ambt van bijzonder hoogleraar

rechtsgeschiedenis van de Limburgse Territoria aan de Universiteit Maastricht op vrijdag 24 september 1999

door

Dr. A.M.J.A. Berkvens

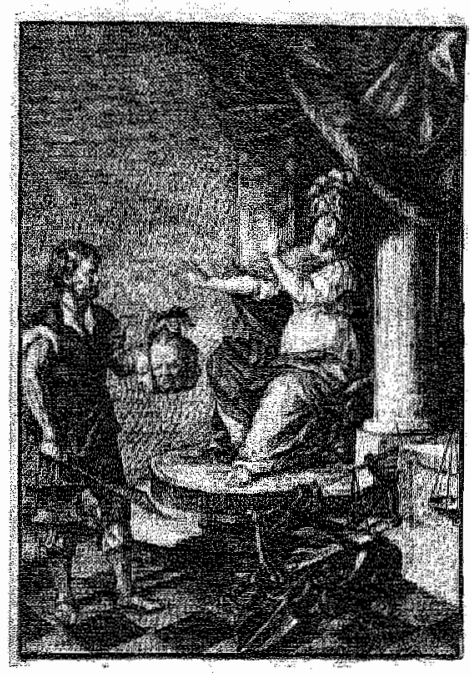

$\mathrm{LGOG}$

Maastricht 1999 
Uitgever: LGOG, Maastricht

ISBN $90-71581-10-1$

(C) 1999, A.M.J.A. Berkvens:

Alle rechten voorbehouden. Niets uit deze uitgave mag worden verveelvoudigd. opges/agen in een geautomätiseerd gegegevensbestand, of openbaar gemaakt, in enige vorm of op enige wijze, hetzij elektronisch, mechanisch, door fotokopieèn, opnamen, of enige andere manier, zonder voorafgaande selhriftelijke toestemming van de auteur.

Voor zover het maken van kopieen uit deze uitgave is toegestaan op grond van art. 16b Auteurswet 1912 jo. het Besluit van 20 juni 1974, Stb, 351, zoals gewijzigd bij het Besluit van 23 augustus 1985, Stb, 471, en art. 17 Auteurswet 1912, dient men de daarvoor verschuldigde wettelijke vergoedingen te voldoen an de Stichting Reprorecht (Postbus 882, 1180 AW Amstelveen). Voor het overnemen van gedeelte(n) uit deze uitgave in bloemlezingen, readers en andere compilatiewerken (art. 16 Auteurswet 1912) dient men zich tot de auteur te wenden. 
Zeer Geache Toehoorders,

\section{INLEIDING}

In september 1778 wendden de naaste verwanten van Laurent Timmermans, gevangene van de heer van Dalenbroek, zich tot de Geheime Raad te Brussel met het verzoek in te grijpen in de criminele procedure die tegen hem was aangespannen voor de schepenbank van Maasniel onder Roermond. Zij wilden bereiken, dat een eventueel door de schepenen op te leggen dood- of lijfstraf op voorhand zou worden omgezet in een desnoods levenslange gevangenisstraf. $\mathrm{Zij}$ opteerden daarbij voor een nieuwe strafsoort, die in de geschriften van verlichte penalisten, zoals Beccaria, werd voorgesteld als alternatief voor levenslange verbanning, lijf-en doodstraf.

Dit verzoekschrift werd, zoals te doen gebruikelijk, door de Geheime Raad het ministerie van binnenlandse zaken en van justitie van de Oostenrijkse Nederlanden - ter fine van advies voorgelegd aan het gewestelijk hof van justitie van Oostenrijks Opper-Gelre, de Soevereine Raad of Hof van Gelre te Roermond.

Kanselier en raden van dit sedert 1580 te Roermond gevestigde college waren reeds met de affaire Timmermans bekend, aangezien kort tevoren van zijnentwege bezwaar was aangetekend tegen het decreet van tortuur, dat op 31

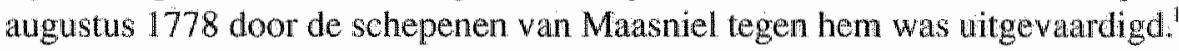
In dit bezwaarschrift werd de toepassing van de tortuur met een beroep op verlichte auteurs principeel verworpen. Emstige vormfouten werden ondanks het formeel ontbreken van mogelijkheden van hoger beroep in strafzaken - aangegrepen voor het instellen van een beroep tot nietigverklaring van het gewraakte decreet. ${ }^{2}$

1 Seder 1715 - Barrieretractaat van Antwerpen - omvatte thet vessort van de Soevereine Raad enkel nog Roemond, het Land van Weart en enkele in de nabijheid van Roermond getegen heerligheden. Voor een beknopt historisch en bibliografisch overzicht van de geschiedenis van de Soevereine Rade te Roermond, zit: A.M.J.A. Berkwens, W.J.H.M. van de Pass en G.H.A. Venner, De Overheidsinstellingen wan Sparns en Oostennjks Gelre (1543-1795), in: A.M.J.A. Berkvents. A.F. Gethlen en G.H.A. Venner (red.). "Flitich erforscht und gecolligeent..." Opstellen over Limburgse rechtsgeschiedenis. Matastricht 1995, blz. 187-225, t.a.p. blz. 193202.

2 Een beroep tot nietigverklaring resulteerde in een onderzoek door de hogere rechter of de lagere rechter zich in zijn rechtsbedeling niet had schuldig genatakt aan bevoegdheidsoverschrijding of schending van substantiele wormvereisten, mei inbegrip van het opleggen wan een abnomaal zware strat. Het appel to nietigverk laring kon alieen leiden tot de nietigverklaring van een deel of het gethel van de procesgang woor de lagere rechter. In dat geval werd het ook het door hem uitgesproken vonnis ventictigd. 
Hierdoor werd het normale verloop van de criminele procedure grondig doorkruist. Ten gevolge van het bezwatarschrift tegen het decreet van tortuur en het daabij gevoegde verzoek tot evocatie, werd het proces feitelijk aan de schepenen van Maasniel onttrokken en overgeheveld naar het Hof van Gelre, dat in eerste atanleg slechts een zeer beperkte bevoegdheid had in strafzaken. Het verzoek tot strafonzetting bracht het proces bovendien onder de aandacht van de Geheime Raad. Hierdoor konden kanselier en raden de zaak miet langer zelfstandig afdoen.

Het is waarschijnlijk, dat de juridische adviseurs van Laurent Timmermans en diens verwanten op deze wijze hun cliënt wilden laten profiteren van de humaniseringstendens in het strafrecht, die sinds 1765 onder invloed van de Verlichting in kringen wan hervormingsgezinde hoge ambtenaren en magistraten van de Oostenrijkse Nederlanden heerste. Zoals bekend was het debat over de hervorming van het strafrecht in 1765 geinitieerd door de gevolmachtigd minister graaf Cobenzl. In een enquête, gericht aan de gewestelijke hoven van justitie in de Nederlanden vroeg hij voorstellen te ontwikkelen om een einde te maken aan de zijns inziens gebrekkige kwaliteit van de criminele rechtspleging in de hoge heerlijkheden en de talrijke onregelmatigheden in de stijl van procederen. Daarnaast peilde hij de bereidheid tot afschafling van tortuur en lijfstraffen. In hun reactie op deze enquête - - en in wetgevingsadviezen nadien - hadden kanselier en raden van de Soevereine Raad te Roermond zich over het algemeen duidelijke protagonisten getoond van humanisering van het strafrecht. ${ }^{3}$

De affaire Laurent Timmermans biedt ons op een aantal punten, zoals professionalisering van de rechtspraak, afschaffing van de tortuur en de introductie van gevangenisstraf als alternatief voor lijf-en doodstraffen, de gelegenheid te laten zien hoe de vernieuwing van het strafrecht in Oostenrijks Gelre en in de Zuidelijke Nederlanden zich in de praktijk voltrok.

Cr: I. Monballyw, De Rad van Vhanderen, een soevereine justitieraad in straftaken ?. in: R. Huijbrecht (fed:), Handelingen van het tweede Hol van Holland Symposium, Den Fatg 1998 (Algeneen Rijksarchief Publikatiereeks nummer 7), biz. 77-90, ta.p. blz. 89.

- A.MJA. Berkvens, Hervorming wan strafrecht en strafprocesreclit in de Zuidelijke Nederlanden in de tweede helft van de achttiende eeuw, in: A.M.J.A. Berkvens e.át. (red.). "Flitich rforscht and gecolligeert ..." Opstellen over Limburgse rechtsgeschedenis, Mastricht 1995, bl: 137-171 


\section{RECHTERLIJKE ORGANISATIE EN STRAFPROCESRECHT}

Alvorens ons nader te verdiepen in de affaire Timmermans is het zinvol een globale schets te geven van de rechterlijke organisatie en het strafprocesrecht in Oostenrijks Opper-Gelre in de tweede helft van de achttiende eeuw. De basis daarvan werd gevormd door de Gelderse Land-en Stadsrechten die, in 1619 door de aartshertogen Albert en Isabella gehomologeerd, in 1620 in werking getreden waren. ${ }^{4}$

Het formele en materiele strafrecht van het Overkwartier van Gelre vindt men in de negen titels van boek 6 van de Gelderse Land- en Stadrechten. De bepalingen van boek 6 richten zich in hoofdzaak tot onderheren, rechterlijke officieren en schepenen. Zij waren in eerste en enige aanleg bevoegd voor de berechting van strafzaken. De Soevereine Raad was volgens zijn instructie in criminalibus slechts bevoegd in gevallen, waarin de hoogheid, heerlijkheid en domeinen van de vorst of diens vazallen in het geding waren, ambtsdelicten van rechterlijke officieren en andere overheidsdienaren, delicten gepleegd door personen die het privilegium fori van de raad genoten, en tenslotte in gevallen van onjuiste toepassing van het recht, casu quo rechtsweigering. ${ }^{5}$ Hoger beroep, reformatie of revisie van strafzaken was volgens het Gelderse Land- en stadsrecht niet toegelaten. ${ }^{6}$

Aan de rechterlijke officieren - ambtman, drost of schout genaamd - en aan de schepenen werden geen bijzondere professionele eisen gesteld. De rechterlijke officieren, die de dubbelfunctie van niet- meesprekende voorzitter van het gerecht en van openbaar ministerie vervulden, dienden slechts "van wettighen bedde" en "nut ende bequaem [te] zijn." ${ }^{\text {"7 }}$ De schepenstoelen moesten worden bekleed met "onbefaembde, redelicke ende verstendige persoonen, sijnde van eerbaer wesens ende wandels, rechter ehelicher gebeurte,

4 A.M.J.A. Berkvens, G.H.A. Venner, G. Spijkerboer (ed.) Het Gelderse Land-en Stadsrecht wan her Overkwartier wan Roernond 1620. Ambem 1996 (Werken Slichting OVR, nr. 25); hierna afgekort GLS. Het is gebruikelijk het GLS te citeren natar paginarummer en artikelnummer.

5 Nye Instuctie 1609, ant $28,36-39,43,44$; de rekst var de kanselarijumstructie ils witgegeven door K.Th.J. Janssen de Limpens, Rechtsbronnen van het Gelders Over$k$ wartier van Roemond, Utrecht 1965 (Werken Vereeniging OVR, 3e reeks no. 20), b/z. 458-469; zie ook" A.M.J.A. Berkvens, Plakkatenlijst Overkwartier 1665-1794, dl. 1, Nijmegen 1990 (Werken Stichting OVR no, 20), blz. 49-55.

6 GLS 336, art 6

7 GLS 1, art. 1 
volcommen alderdoms, ten minsten van dertich jaeren, tamelick onder 't gericht daer sij gecosen worden gegoit ende geërft." Zij die konden lezen en schrijven en kennis hadden wan het landrecht, de oude gewoonten en gerechtelijke aangelegenheden, genoten daarbij de voorkeur.

Eenmaal aangesteld, konden zij slechts door rechterlijke tussenkomst worden afgezet. Indies een schepenbank niet volledig bezet was, kon men hem completeren, door schepenen van naburige banken te assumeren. ${ }^{10}$ Tussenkomst van de complete schepenbank was vereist op een drietal vitale punten van het strafproces: Zij beslisten over de aanhouding van de verdachte door het al dan niet verlenen van een decreet van corporele apprehensie. $\mathrm{Zij}$ konden de verdachte door middel van een decreet van tortuur naar de pijnbank verwijzen. En zij veroordeeden hem eventued tot lijf- of doodstraf.

Aangezien hoger beroep, reformatie of revisie in strafzaken niet mogelijk was, had de Soevereine Raad vrijwel geen competentie in criminalibus en oefenden de sehepenbanken de criminele jurisdictie in beginsel zelfstandig uit. Voor zover zij behoorden tot het ressort van het Hoofdgerecht van Roermond, konden zij zich in problematische gevallen "der saecke onwijs" verklaren en hoofdvaart instellen. In dat geval concipieerden de overwegend juridisch geschoolde Roermondse schepenen een vonnis, dat de subalterne schepenen vervolgens overnamen en als hun eigen vonnis uitspraken. In de achttiende eeuw gold deze regeling nog voor de schepenbanken van Elmpt, Cruchten en Wegberg. "In de vrije heerlijkheden, zoals Dalenbroek, Meyel, Obbicht en Pappenhoven, Weert, Wessem en Nederweert, was het in dergelijke gevallen gebruikelijk advies in te winnen van advocaten. ${ }^{12}$

Bij de uitoefening van de criminele jurisdictie waren rechterlijke officieren en schepenen gebonden aan boek 6 van het Gelderse Land- en Stadsrecht. De cerste rwee titels van dit boek behandelen het onderscheid tussen boetstratfelijke en lijfstraffelijke delicten, respectievelijk aangeduid als "misbruicken" en "misdaden". De titels 3-6 regelen de vervolging van de in titel

\$ GLS 1, art, 3,4

* GLS I. int. 2

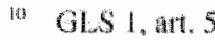

11 O.H.A. Venner, Het Hoofdgereht Roemond, in: PSHAL 122(1986) blz. 30-99. t.a.p. bliz. 79

12 GLS 335 3, art. I verbied het ratdplegen van rechtsgeteerde adviseurs; deze bepaling geld niet voor de vrije heerlijkheden, omdat het GLS hier eerst op het einde van de geventiende eeuw is ingevoerd, toen het inwinnen van rechtsgeleerd advies in de vrije heerlijkheden reeds de gevestigde praktijk was. 
2 beschreven "misdaden"; terwijl in de drie resterende titels enkele bijzondere onderwerpen worden behandeld, zoals het purgatieproces, vredelegging en de zoenprocedure.

In het hiema volgende wil ik mij met name concentreren op de titels 3-6, betreffende de vervolging van "misdaden". Titel 3 regelt aanhouding: borgstelling en ondervraging van de verdachte; titel 4 beschrijft het daaraan yoorafgaande opsporingsonderzoek en de verstekprocedure. die gevolgd moet worden indien het onderzoek niet leidt tot aanhouding van de verdachte; litel 5 is gewijd aan de pijnlijke ondervraging. Deze kan zowel plaatsvinden in het kader van de in vitel 3 beschreven ondervraging, als in het kader van de behandeling ter terechtzitting, die wordt beschreven in titel 6 .

Het is zinvol eerst enkele onderdelen van titel 4 "Van ondersueck op swaere misdaeden ende vervolgh tegens de verloepene misdaedighe" te bespreken, omdat hier de rechten en plichten van het openbaar ministerie in het opsporingsonderzoek of inquisitio generalis worden beschreven.

Drosten, ambtlieden, scholtissen en gerichtsluiden waren verplicht hum uiterste best te doen alle zware misdrijven te vervolgen, op straffe van vervolging in geval van nalatigheid. ${ }^{13} \mathrm{Zij}$ moesten daarbij echter met de nodige omzichtigheid te werk gaan, want indien zij iemand lichtvaardig beschuldigden, dan stond het hem wrij zich daarover bij het Hof van Gelre te beklagen. ${ }^{14}$ Deze bepaling vormde niet alleen een garantie tegen knevelarij, maar bood ook de mogelijkheid, door middel van evocatie, de behandeling van een zaak aan de lokale officier te onttrekken.

Een dergelijke waarborgfunctie vervulden ook de artikelen 9 e.v, waarin werd bepaald, dat de officier tegen niemand mocht procederen "bie inquisitie ofte ondersueck", tenzij er sprake was wan een ernstig delict, waarvan vaststond dat het inderdaad was gepleegd, en er een redelijk vermoeden van schuld was ten opzichte van een bepaalde verdachte. Deze wijze van procederen was cchter niet toegelaten tegen personen wan goede naam of faam, zolang er tegen hen geen redelijke gronden van werdenking waren gerezen. Indien er slechts sprake was van "gemeinen roep, gerucht ende fame", dan was de officier gehouden eerst een onderzoek in te stellen naar de betrouwbaarheid van het gerucht, alvorens een persoon die te goeder naam en faam bekend stond aan te tasten. Slechts indien de informatie afkomstig bleek van "wettige ende tuychbaere persoenen", kon de officier het onderzoek openen en aanhouding en

1.7 GLS 376, att. 1

if GLS376. ant 3 
gevangenhouding wan dergelijke verdachte vorderen. ${ }^{15}$ Door een tijdig beroep op deze bepalingen kon men verlening van cen decreet van apprehensie en daarmee een strafproces voorkomen. ${ }^{36}$

Gedurende de voorbereidende fase was het verhoor van getuigen niet aan vormvoorschriften gebonden. Indien men zich in een later stadium van her proces van hun verklaringen wilde bedienen om te komen tot veroordeling van een verdachte, dan moest " $\mathrm{d}$ " oirdre van de gerichtelijke proceduere in't verhoiren van de getuygen" alsnog worden gevolgd. Dit betekende, dat gedurende het eerste verhoor de namen van getuigen en de inhoud van hun verklaringen voor de verdachte verborgen bleven en dat hij pas zodra de olficier "ten thoon" was toegelaten, in de gelegenheid werd gesteld getuigen te wraken en van tegenbewijs te dienen." Dit hield, zoals in de affaire Timmermans zal blijken, een belangrijke beperking in van de mogelijkheden tot effectief verweer namens de verdachte.

Titel 3 van boek 6 regelde de aanhouding, opsluiting en ondervraging van verdachten, die in het GLS overigens consequent als "misdadigers" werden aangeduid. Hierbij werd ten aanzien van de mogelijkheid van borgstelling onderscheid gemaakt tussen enerzijds vreemdelingen, niet-ingezetenen, die ongeacht een aanbod van borgstelling in hechtenis genomen mochten worden, indien daartoe op grond van het opsporingsonderzoek voldoende aanleiding was", en anderzijds burgers en ingezetenen, die in beginsel door borgstelling aan gevangenhouding konden ontkomen, welk recht zij niet genoten indien zij op heterdaad betrapt waren of wanneer het een feit van algemene bekendheid betrof. ${ }^{\text {is }}$

Zodra een verdachte aldus was "aangetast", nam de inquisitio specialis een aanvang met diens verhoor door de rechterlijke officier, in aanwezigheid van twee schepencommissarissen en de gerechtsschrijver. De basis wan het verhoor werd gevornd door een "scliriftelick vermeet van belastinge" of "feyten van belastinge", opgesteld door de rechterlijke officier. Dit vermeet van belastinge, veelal het resultaat van het opsporingsonderzoek, behelsde in de vorm van vraagpunten een beschrijving van de feiten die de officier te laste wilde leggen. Op deze vragen diende de verdachte, die ter voorkoming van meineed niet

GLS 377, ant $9-11$

th RAl, Hof van Venlo, inv.nr. 1074, affaire Gerard Slangen

GLS 378, art. 12-13

18 GLs 373, art 1.5 
onder ede gesteld was, semotis advocato et procuratore, d. w.z zonder advocaat of procureur, te antwoorden, de zgn "personele responderinge". De verklaring van verdachte werd op schrift gesteld, waarbij men met name ook diende te letten op diens gemoedstoestand. ${ }^{19}$

Indien de verdachte tijdens het eerste verhoor een bekentenis aflegde, dan moest de officier diens bekentenis ambtshalve verifièren. Bleek zijn verklaring niet met de feiten overeen te stemmen, dan kon hij hem daarover opnieuw ondervragen, desnoods met gebruikmaking van de pijnlbank. ${ }^{20}$ De regel confessus pro convicto habetur - degene die bekent wordt geacht schuldig te zijn - mocht volgens het Gelderse Landrecht kennelijk niet worden toegepast. Een ontkennende verdachte diende in de gelegenheid gesteld te worden zijh onschuld of alibi te bewijzen. Nadrukkelijk stond in de gehele procedure het achterhalen van de materiele waarheid voorop: "opdat soewel bekendt magh worden sijn onnoeselheit ende onschuldt als belastinge." Schout en schepenen waren gehouden al hetgeen tot ontlasting of belasting van de verdachte zou kunnen dienen terstond te doen noteren. ${ }^{21}$

Indien het openbaar ministerie niet tevreden was met de personele responderinge, lag het voor de hand, dat de rechterlijk officier zou willen komen tot "naerder bericht van die watheit ende gelegentheit van het misdaet, daermede hij den gevangen wilt betichten ende belasten". In dat geval vorderde hij dat de rechtbank de verdachte naar de pijnbank zou verwijzen. Verwijzing ter tortuur kon zowel tijdens het eerste verhoor worden gevorderd, als in het kader van de eigenlijke bewijsprocedure.

De toepassing van de tortuur was onderworpen aan zeer gedetailleerde voorschriften. Het openbaar ministerie mocht niemand ter tortuur stellen, zonder rechterlijk decreet of tussenvonnis van de complete schepenbank. Alvorens het gevraagde decreet te vertenen; moest volgens de Gelderse Landen Stadsrechten aan drie kriteria voldaan zijn: de schepenen moesten "wel bericht zijn" van de omstandigheden van het geval; de schuld van de verdachte moest zeer waarschijnlijk zijn; en de aard van het delict moest zodanig zijn, dat veroordeling tot lijfstraf in de rede lag. ${ }^{22}$ Met andere woorden, de schepenen moesten zich op voorhand een oordeel wormen over de mogelijke uitslag van het proces, alvorens een verdachte ter tortuur te stellen.

\footnotetext{
GLS 374, art. 7-11

20 OLS 375, art. 12

211 GLS 375, art. 13-14

22 GLS 380. art. 1-3
} 
Het pijnlijk verhoor zelf vond plaats in aanwezigheid van twee schepencommissarissen, die bepaalden hoe lang en tot welke graad er gepijnigd moeht worden. Zij dienden er daarbij op toe te zien, dat verdachte niet emstig gekwetst werd en dat de pijniging werd aangepast aan de persoon, het strafbare feit en het voorliggende bewijs. ${ }^{23}$ Schout en schepenen moesten de verklaring van verdachte op schrift doen stellen door de gerichtssecretaris, en daarbij letten op alles dat tot belasting of ontlasting van de verdachte zou kunnen bijdragen. De verdachte kon niet enkel op grond van hetgeen hij onder torturur verklaard had worden veroordeeld. Hij moesi daarom zijn bekentenis "onder den blauwen hemel, ende buiten alle hachten ende banden van iseren" ten overstaan van de schepenen herhalen, de zogeheten recollectio sub dio, welke binnen vierentwintig uur moest platsvinden. ${ }^{24}$ Als de gevangene de tortuur had doorstaan, mocht hij niet opnieuw gepijnigd worden, zonder dat er sprake was van nieuwe aanwijzingen. Deze regel gold echter niet in het geval hij zijn bekentenis herriep; indien de aanwijzingen tegen hem zo zwaar waren, dat zij door de eerste tortur niet voldoende gezuiverd waren, of als hernieuwde pijniging noodzakelijk was met het oog op de ontdekking van medeplichtigen. ${ }^{25}$ Indien een gevangene bij zijn ontkenning bleef, dan mocht bij nog enige tijd worden vastgehouden, maar wanneer zich geen nieuwe aanwijzingen tegen hem voordeden, dan moest men hem vrijlaten, mits doende oirvede, d.w. $z$ de gevangene moest plechtig beloven zich niet te zullen wreken. ${ }^{26}$

De eigenlijke behandeling ter terechtszitting werd geregeerd door titel 6 van boek 6 "Van betichtinge ende gerichtlick verwolgh der gevangenen ende vonnissen daerop gegeven". Ook in deze titel werd het beginsel van ambtshalve vervolging van misdaden voorop gesteld. De rol van de gelaedeerde, of diens nagelaten betrekkingen, beperkte zich tot het doen van angifte en het desgewenst optreden als gevoegde partij. In het Overkwartier prevaleerde het inquisitoire beginsel boven het accusatoire beginsel. ${ }^{27}$

De inhoudelijke beschrijwing van de procedure was zeer beknopt. De rechterlijke oflicier diende binnen drie dagen na de apprehensie de aanklacht (clacht ende aenspraecke) in te dienen, op straffe van ontslag van

2 GLS 380, ant. 5; GLS 382, art. 14

2. GLS 383 , ant 16.18

25 GLS 383, ant 19

36 GLS 384, ant. 22, 23

2 Cfr. J.H. Drenth. Bijdrage 10 de kennis der historische onlwikkeling van hel accusattoime tot het inquisitoire strafproces, Amsterdam 1939 (Diss. VU), ble. 18-22 
rechtsvervolging van de verdachte. Deze aanklacht werd als regel gebaseerd op de (provisionele) feiten van belasting, die in het vooronderzoek waren gebruikt. De scheiding tussen vooronderzoek en behandeling ter terechtzitting is daardoor niet altijd even duidelijk. Hoewel dit in boek 6 niet nadrukkelijk was voorgeschreven, vorderde de rechterlijke officier in dit stadium van het proces, dat aan de verdachte een "bediende" (advocaat of procureur) zou worden toegewezen om namens hem van antwoord te dienen. ${ }^{28}$ Een officier die dit naliet, riskeerde een ingrijpen van het Hof in de procedure. ${ }^{29}$ De bereidheid van advocaten en procureurs deze "bediening" te aanvaarden was vaak zodanig gering, dat zij op straffe van boete daartoe verplicht moest worden. ${ }^{30}$

In lijfstraffelijke zaken diende de procedure van "onvertogen recht" te worden gevolgd, d.w.z. dat van dag tot dag werd geprocedeerd. ${ }^{31}$ Hiertoe werden naar behoefte extraordinaris gerichtsdagen gehouden. In boetstraffelijke zaken daarentegen volgde men de procedure van ordinaris rechtsvordering, d.w.z. men procedeerde van acht dagen tot acht dagen, zodat de ordinaris gerichtsdagen volstonden. ${ }^{32}$

Zodra de rechterlijke officier meende dat de zaak woldoende was geinstrueerd, nam hij of zijn procureur mondeling conclusie van eis. Deze eis hield geen vordering van een specifieke lijf- of doodstraf in. Men verzocht slechts, dat verdachte "gestraft zal worden nae recht ende justirie, gelijck dergelijcke misdadigen gestraft behoeren te werden, anderen tot ein exempel, oft mit

2* Deze verplichting wordt afgeleid uit GLS 375 , art. 14, waarin wordt gesteid dat de officier zorg moet dragen voor hei achterhalen van de materiële watheid en daarbij niet alleen moet letten op feiten die de verdachten betasten, matr ook op feiten die in diens voordeel spreken. Cfr. RAL, Hof van Venlo, inv. 1080, remonstrantie wan momboir M. van Wessem. GLS 305, art. 1 bepaalt weliswaar, dat partijen zich door rechtskundige adviseurs kunnen laten bijstan. Wen verplichte procesvertegenwoordging in strafzaken lat zich uit dit artikel niet afleiden.

29 Indien de officier dit verzuimt, wekt hij de indruk exen extraondinaite procedure to willen voeren; deze procesvorm is in het Overkwartier ongebruikelijk; cft. RAL. Hof van Verlo, inv. nr. 62, affare Smeets 1762

3f In 1761 weigerde procurewr Dionysii aanvankeljk Johannes Scmin, gevangene vin de drossaard van Montfort, te verdedigen, ondat hij nog niet schadeloos gesteld zou zijn woor de kosten die hij had moeten maken voor de verdediging wan Henricus Freets, die een jatar eerder te Beesel was geexecuteerd. Hel hoofdgerecht Echt had diens declaratie als exorbitant van de hand gewezen. RAL, Archieven van overheidsfunctionarissen in het ambt Montfori, inv.ni. 1556.

3) Deze regel mocht echter niet zodanig strikt worden gehanteerd, dat men de vendachio daardoor de gelegenheid ontnam on bewijs vatn zijn onschuld te leveren. Cr. GLS 284, art. 1

G. GLS 282, art. 1 
andere alsulcken pene, als "t gericht in redenen ende billicheit sal bevinden te behoeren. ${ }^{133}$ Door een dergelijke algemene formulering te kiezen werd voorkomen, dat een onjuiste formulering van de eis zou leiden tot onbedoelde vrijspraak van de verdachte.

Het gerecht mocht niemand ter dood veroordelen, tenzij hij het feit had bekend, of tilt het voorgelegde bewijs zijn schuld zonneklaar gebleken was. De jurisdictie-heer of scholtis was op straffe van banksluiten ${ }^{34}$ verplicht het gewezen vomis ten uitvoer te leggen.

Indien de schepenen van oordeel waren, dat de verdachte ten onrechte was vervolgd, dan kende het Gelderse Land en Stadsrecht aan de vrijgesproken verdachte een aantal mogelijkheden van werhaal toe, hetzij op de rechterlijke officier, hetzij op de aambrenger. ${ }^{35}$ Eenmaal vrijgesproken, kon de verdachte niet meer voor hetzelfde feit opnieuw worden vervolgd, het bekende ne-bis-inidem-beginsel.

\section{APPRECIATIE VAN HET GELDERS OVERKWARTIERLIIKE STRAFPROCESRECHT} $(1765 / 1766)$

Of en in hoeverre toepassing van het strafprocesrecht van het Gelderse Landen Stadsrecht in de tweede helft van de achttiende eeuw als problematisch werd gezien, kan men opmaken uit het advies terzake van de administratie van de criminele justitie, dat kanselier en raden in 1766 opstelden ter voldoening aan het eerder gememoreerde verzoek van de gevolmachtigd minister, graaf Cobenzl. $^{36}$

Uit dit advies blijkt, dat kanselier en raden techniseh gezien, behalve voor wat betreft de toepassing van de tortuur, uitermate tevreden waren met de regels van strafprocesrecht, zoals neergelegd in het GLS, maar dat zij zich grote zorgen makten over de professionaliteit van de schepenbanken, die deze regels moesten toepassen.

GiLS 385. art. 7

Banksluten, di. stilleggen van de rechtspraak door de schepenen ten einde de rechterlijke officier te dwingen een gewezen vonnis ten uitvoer te leggen; cfr. K.J.Th. Janssen de Limpens, Banksluiten in her Overkwartier van Roermond, in: De Maasgouw 81 (1962) kol. 169-176. 
Gesteld voor de vraag of het wenselijk zou zijn ter voorkoming van onregelmatigheden in de stijl van procederen de gerechten te verphchten de aloude Criminele Ordonnantien van Filips $\mathrm{I}_{\text {, }}$ en met name de Ordonnantie op de Stijl van procederen van 9 juli 1570 na te laten volgen, stelden zij zich op het standpunt, dat de compilatoren van het Gelderse Land-en Stadsrecht zich bij hun werkzaamheden hebben laten leiden door deze ordonnantie, en dat deze de Ordonnantic op de Stijl in grote lijnen volgen, maar dat er nasid overeenkomsten ook duidelijke werschillen aan te wijzen zijn. In een uitvoerige bijlage, waarin men de Ordonnantie op de Stijl niet als geldend rech, matr als een alternatief ius comstimendum behandelde, werden successievelijk alle artikelen van deze ordonnantie becommentarieerd, waarbij de vergelijking wan hun inhoud met die van het Gelderse Land- en Stadsrecht van 1619, yoor zover op dezelfde materie betrekking hebbend, steeds in het voordeel van het laatste uitviel. Telkens werd erop gehamerd, dat al wat in de Ordonnantic op de Stijl woorgeschmeven werd, op gelijksoortige of betere wijze ook in het Gelderse Land-en Stadsrecht geregeld was. Naar hun mening waren de voorschriften van het Gelderse Land en Stadsrecht niet alleen posterieur maar ook superieur an de Ordonnantie op de Stijl. Bovendien waren zij ook in overeenstemming met de additionele voorschriften van het Eeuwig Edict van 12 jul $1611 .{ }^{3 .}$

Waar kanselier en raden aldus in grote lijnen positiof waren over het Gelders Overk wartierlike stralprocesrecht, waren zij dat niet over de kwaliteit wan de rechters die dit recht moesten toepassen. In laun adwies constateerden zij zonder meer, dat ook in Oostenrijks Gelre het misbruik wijd verbreid was, dat plattelandsschepenen, zonder enige kemis van de criminele jurisprudentie, met advies van rechtskundigen die er evenmin veel kaas van hebben gegeten, lijfstraffen uitspraken en de doodstraf oplegden, zonder enige mogelijkheid van hoger beroep.

Zonder hierover met voorbeedden uit te wijden - sedert het Discours des abus des justices de village van Chatles Loyseau (1564-1627) was de incompetentie van rurale schepenbanken toch al een gemeenplaats onder de intellectuele elite - en zonder verdere negatieve kwalificaties van de schepenen ten platitelande,

3 O. Moorman van Kappen, De rechtskracht van de Ordonnantie op de Stijl van procederen in criminele zaken van 9 juli 1570 in de Oostenrijkse Nederlanden, in: TRG 58 (1990) blz. 327-343, ta.p. blz. 337-341.

3. Les Oevres de maistre Charles Loyseau ... contenant le discours des abus des justices de willage, Parijs 1678 ; cr. de citaten bij $1 . J$. de Wit; Inwendige toestanden in ankele heerlijkheden, maar vooral in de vrije rijksheerlijkheid Rijokholt in de $17 \mathrm{e}$ en $18 \mathrm{e}$ eeuw, in: PSHAL 52 (1916) blz. 74-188, top. blz: 95 e.w. 
zoals men die enkele jaren later in memories over de gebrekkige kwaliteit der schepenrechtspraak in Stats en Pruisisch Opper-Geire wel zou aantreffen, constateerden kanselier en raden dat het onwenselijk was de criminele rechtspraak nog langer over te laten aan schepenen zonder enig benul van het recht, die soms lezen noch schrijven konden en geen serieus tegenwicht vormden voor de jurisdictieheer die hen benoernde.

Hoewel de momboir of procureur-generaal, om de wel juridisch geschoolde schiepenen van het Hoofdgerecht van Roermond niet voor het hoofd te stoten, laad voorgesteld, dat voor de schepenbanken uit diens ressort in criminele zaken het instellen van hoofdvaart verplicht zou worden - een methode overigens die in het graafschap Loon en het daarbij gevoegde graafschap Horn in 1752 opnieuw nadrukkelijk was voorgeschreven - en dat de vonnissen van de schepenbanken der zgn. vrije heerlijkheden - naar analogie van de reeds in 1727 in Pruisisch Opper-Gelre ingevoerde regeling - aan goedkeuring van de Soevereine Raad onderworpen zouden worden, stelden kanselier en raden zich op het standpunt, dat alle vonnissen en tussenvonnissen in strafzaken voortaan aan de goedkeuring van de Soevereine Raad zouden moeten worden onderworpen. ${ }^{40}$ De meerkosten die een dergelijk approbatierecht met zich zou brengen, zouden gemakkelijk gecompenseerd worden doordat de kosten die voorheen werden veroorzaakt door de gebrekkige instructie van strafzaken, dankzij het toezicht van het Hof aanzienlijk zouden dalen. Uitvoering van dit nog betrekkelijk behoudende voorstel - enkele jaren later zou men in het aangrenzende vorstendom Thorn de schepenrechtspraak compleet afschaffen ${ }^{41}$

3 Cr. Memorie van de Prutsische groot-kanselier Von Camer over de verbetering van het Justitiowezen in Prusisch Opper-Gelre van 16 october 1783 , afgedrukt als bijlage bij A.I.A. Flament, De rechrbedeeling op het grondgebied van de tegenwoordige provincil Limburg in 1794 met cen blik op de voorgeschiedenis, in: PSHAL 3) (1915), bli. 1-87, ial.p. blz. 79-87. Zle ook RAL, Archieven van overheidsfunctionarisson in het ambt Montort, inv. hr. 1565, memonies betreffende de herimohting Wan rechtspraak on bestuur in het ambe van Montfort, 1773,1778 en 1779.

* Een dergelijk approbatierech werd door het Hof van Gelre te Amhem uitgeofend ten asnzien van de criminele rechstpleging in het Kwartier van Nijmegen. Zie hierower witvoerig de voorteffelijke dissertatie van mev. D.A.J. Overdijk, De gewoonte is de beste witleg van de wet. Een onderzok naar de invloed wan het Hof van Gelre en Zutphen op de rechspleging in criminele zaken in het kwarter van Nijmegen in de zewentiende on achthiende eeuw, diss. Nijmegen 1999 Rechtshistorische Reeks van het Geratrd Noodt Institut ni. 43).

4) A M.J.A. Berkwens, Het Nieuwe Landrecht wan Thom. Verlicht absolutisme en codificatie onder het bewind van de vorstin-abdis Maria Cunegonda van Saksen (1776-1794), in: E.C.C. Coppens (red.), Honoris Causa. Opstellen aangeboden aan prof.mr. O. Mooman van Kappen. Nijmegen 1999 (Rechtshistorische Reeks Gerard 
- zou kanselier en raden ook in stat stellen toczicht wit te oefenen op de toepassing van de tortuur.

Over de afschaffing van dit onderzoeksinstrument bestond verschil in inzicht tussen de momboir of procureur-generaal en de radsheren in do Soevereine Raad. Volgens de procureur-generaal was de tortuur een noodzakelijk kwaad ten behoeve van een efficiente strafrechtspleging. Zijns inziens was de tortuur in de handen van een integere en helderiende rechter die er met verstand gebruik van maakte een zeer nuttig instrument om te zorgen, dat misdadigers hun verdiende straf niet ontiepen en hun medeplichtigen te achterhalen. Ook stond hij positief tegenover de heilzame generaal preventieve werking die ervan uitging. Hij realiseende zich echter terdege dat de tortur in de handen van een "juge indiscret" gemakkelijk zou kunnen verworden tot een bron van gruwelen en onrecht. Om deze reden kon men de toepassing van de tortuur niet aan plattelandsschepenen overlaten, want deze woldeden helaas niet aan dergelijke hoge eisen van oordeelkundigheid en bekwaamheid.

Dit opportunistische standpunt werd door de raadsheren in de Soevereine Raad niet gedeeld. Kanselier en raden stelden zich op het standpunt, dat torturr en gerechtigheid principieel met elkaar in strijd zijn en dat de tortuur om die reden alleen al afgeschaft zou moeten worden.

Dat tortuur strijdig is met het recht, blijkt naar hun mening wanneer men dwang in het burgerlijk recht vergelijkt met dwang in het strafrecht. Indien in het burgerlijk recht een overeeenkomst onder dwang tot stand is gekomen, dan wordt aan de afgedwongen toestemming ("aveu extorqué") geen geloof gehecht, met andere woorden, de overeenkomst is vamietigbaar. Het kwam kanselier en raden vreemd voor, dat men dan in strafzaken an een afgedwongen bekentenis ("aveu extorqué") wel geloof zou moeten thechten, en wel op zodanige wijze, dat een rechter met gerust geweten iemand, die aldus onder dwang had bekend, ter dood zou kunnen veroordelen.

Dat de tortuur onzeker en bedrieglijk is in zijn gevolgen, werd door kanselier en rader als volgt geadstrueerd. In de bedoeling van de wetgever diende gebruk van de tortuur te resulteren in de ontdekking van de watheid door de mond van de verdachte. Mar hoe kan de rechter weten of de verdachte de waarheid spreekt? Het bewijs tegen verdachte is nog niet compleet; de rechter twijfelt derhalve nog aan diens schuld; de verdachte kan onschuldig zijn. De

Noode Instituth nar. 42) blz. 1.28.

4. Cf. ant $1485 \mathrm{BW}(1838)$ en ant. 3.49 e.v. BW. 
rechter veroordeelt verdachte tot de tortuur en accepteert, dat hij mogelijkerwijs een onschuldige toevertrouwt aan de handen van de beul. De uitslag wordt nu bepaald door de stamina van de patient. Een schuldige verdachte met een groot uithoudingsvermogen is zeer well in staat de tortuur zonder te bekennen te doorstaan; een onschuldige verdachte met een lagere pijndrempel zal "comine le juge lui-même peut-être auroit fait à sa place" - bezwijken onder de pijniging en als een gebleken schuldige ter dood veroordeeld worden. Met instemming citeerden zij Ulpianus die ten aanzien van de tortuur opmerkt, dat men dit onderzoeksinstrument zeer voorzichtig moet hanteren: etenim res est fragilis et periculosa et quae veritutem fallat. ${ }^{43}$

Kanselier en raden schoven het argument van de momboir, dat de tortuur een oud en beproefd hulpmiddet is, terzijde met de opmerking "que la pratique d'un moyen prouve injuste, de plus inutilement cruel, et manquant souvent le but que la loi se propose, ne peut jamais passer pour être nécessaire." Zij waren van mening, dat de tortutur evenals de godsoordelen bijgezet moest worden in het rijtje van achterhaalde onderzoeksnethodes en dat het inwinnen van informatie door de openbare aanklager, door middel van ondervraging en onderzoek, de enige betrouwbare methode was om de (materiële) waarheid te achterhalen. Zowel godsoordelen als tortuur hebben er regelmatig toe bijgedragen, dat onschuldigen werden veroordeeld en schuldigen vrijgesproken. Godsoordelen zijn inmiddels al eeuwen afgeschaft, en niemand verlangt ernaar terug. En dat men zonder tortuur kan, blijkt in Engeland, waar men deze volgens Montesquieu met succes heeft afgeschaft, en ook in Pruisen, waar dit eveneens is geschied. $^{44}$

Een andere tegenwerping die zij voorzagen, was dat zonder de tortuur heel wat misdaden ongestraft zouden blijven. Kanselier en raden tilden hieraan niet zwaar. Zij vonden dit verkieslijker, dan dat een onschuldige burger ten onrechte aan de tortuur zou worden blootgesteld.

Daurmee kwamen zij toe aan een derde mogelijke tegenwerping. Stel, dat de regering bereid zou zijn de tortuur voor nette burgers, die eenvoudig onder

D. $48,18,1,23$

44 Verwezen wordi natr Montesounu, De fespit des Lois, dl. 1, bk. 6, hfdst. 16; dit moet zijn hfdst. 17, al watr ten atmzien wan de tortuur wordt opgernerkit:" nous voyons aujourd'hui une nation (la nation Anglaise) très bien policés la rejeter sans inConvênient. Elle nest donc pas nécessaitre par sa nature." Voor wat betreft Pruisen wordi verwegen nar de titel "Des raisops détablir ou abroger les lows", in de Histaire de Bhandebourg. Frederik II schafte bij zijn troonsbestigging in 1740 de pligbank af voor alle gevallen, met uitzondering van "Massenmord", landverraad en majesteitsschemis. In 1754 verbood hij ze volledig. J.M. Micntels, Cesare Beccaria. Over wisdaden en Siraffen. Antwerpen/Zwolle ${ }^{2} 1982$, blz: 89, nt. 1. 
controle te houden zijn, at te schaffen, zou men dan een dergelijke gunst ook moeten bewjzen aan vagebonden en lieden zonder middelen van beswan, "deja punisibles par cette qualité seule; souvent d'un caractere atroce et savage; que le juge, ..., na aucun noyen de connoitre: qui dans l'obscurite vientent infester la parrie, y commetre des vols, des meutres, des incendies. "Waturom zou men dergelijke lieden niet behandelen, zoals de Romeinen hun slaven - met andere woorden, hen biloot stellen aan de tortuur?

Kanselier en raden stelden zich hier op het standpunt, dan men wagebonden weliswar niet met dezelfde égards hoefde te behandelen als nette burgers; maa het ging hen te ver om hen, zonder wettig bewijs, te straffen alsof zij schuldig waren aan misdaden, omdat zulks in strijd zou zijn met de menselijkheid. $2 \mathrm{ij}$ merkten op, dat de tortuur geen geschikt middel was on de overhast van vagebonden en lieden zonder middelen van bestaan te beperken. Zuj verwachtten in dit opzicht meer heil van de oprichting van een "maison de force", alwaar men dergelijke lieden voor eeuwig, of voor bepalde tijd zou kumnen opsluiten en waar zij door middel van dwangarbeid in hun onderhoud zouden moeten voorzien. Deze gevangenis zou tevens plaats kunnen bieden voor burgers, die zijn veroordeeld tot straffen zwaarder dan verbanning, mar minder dan de doodstraf. Zij gaven de landvoogd in overweging een dergelijke gevangenis te doen oprichten, hetzij woor Oostenrijks Gelre alleen, hetzij met de landen van Limburg en Overmaze gezamenlijk, dan wel goed te vinden, dat de veroordeelden unt deze gebieden hun straf in Brabant zouden ondergaan. ${ }^{\text {s. }}$ Bezien wij thans aan de hand van de casus Laurent Timmermans, hoe kanselier en raden hun ideeen in praktijk brachten.

45. In 1771 hebben kanselier en raden in een nader advies over de affochalfing van de tortuur en de oprichting var verbetedituzen geple it wor de afschaffing wan lifstratfen en vervanging daarvan door gevangenistraf, conform de voorstellen. woals datutoe geformuleerd door Goswin de Fierlant in diens Observasions sur " intuffisante ef inconveniens des peines affichwer. A.M.A. Berkvens, Herworming wan shafrech en strafprocesrecht, ble. $154-156$ 


\section{DE CASUS LAURENT THMMERMANS}

Het proces tegen Laurent Timmermans kan men aan de hand van de criminele $\mathrm{rol}^{46}$ en van het procesdossier ${ }^{47}$ goeddeels reconstrueren. Bij zijn aanhouding te Leeuwen - een onder de schepenbank Maasniel ressorterend gehucht van de heerlijkheid Dalenbroek - had Timmermans aanvankelijk een valse naam opgegeven, zodat de preparatoire informatie van 28 maart 1778 ten name van Martinus. Willens was gesteld Nadat zijn juiste identiteit was gebleken, werd het proces vervolgd met een nader verhoor ten overstaan van twee schepencomimissarissen en de secretaris van Maasniel op het raadhuis te Roemond ${ }^{48}$ Gedurende het preparatoire verhoor en het naerder verhoor genoot Timmermans geen rechisbijstand. Naar aanleiding van de verklaringen die Timmermans tijdens het verhoor heeft afgelegd, heeft de schout van Dalenbroek op diverse plaatsen, o.a. in de Meierij van 's Hertogenbosch en in het hertogdom Gulik nadere inlichtingen ingewonnen over delicten, die Timmermans toegaf te hebben gepleegd. Nadat de gewenste inlichtingen waren ontwangen, heeft de schout van Dalenbroek - na enkele malen aitstel te hebben verzocht - op 18 april 1778 de provisionele feiten van belastinge ingediend, welke op 21 april met enkele additionele feiten van belastinge werden uitgebreid.

Op 22 april diende de procureur Schreurs ${ }^{49}$ namens de heer en de schout van Dalenbroek zijn voorlopige aanklacht in. Hij beschuldigde Laurent Timmermans van oplichting, domestieke diefstal en negen andere diefstallen, waarvan drie met braak. Bovendien zou hij in twee gevallen uit hechtenis zijn ontsnapt, te Helmond in 1772 en te Elmpt in 1774. Tenslotte werd hij ervan beschuldigd zich te hebben laten ronselen voor dienst bij Pruisische troepen, en zou hij zelf als ronselaar voor Paltische troepen hebben gefungeerd. Namens

4h GAR, heerlikheid Dalenbroek, inv. 64 (microfm RAL)

a) GAR, heerlijkheid Dolenbrok, inv. 564 (microfilm RAL)

ax De criminald procedure vindt overwegend plaats ten overstaan van schepencommissarissen. Slechts indien er een (tussen-) womnis moet worden gewezen, dient de bank te worden gecompleteend.

40. Jan Mathias Schteurs (1745-1804) was in de loop van zijn carriere 0.a. schout der heerlikheid Dallenbroek, procureur en notaris te Roemend an - in de franse tijd hypotheekbewatder en griffier van het Vredegerecht aldad. E.M.A.H. Delhougne, Roermondse geslachten, dl. 1, Maastricht 1956, biz. 186. Volgens F.L. Hartong, Register def protocollen van notarissen in Nederiand, Rotterdam 1916, ta.p. b. 222 en 500 , zijn wan hem protocollen overgeleverd uit de periode 1772-1798; zie ook Verslagen omtrent "s Rijks oude Archieven 34(1911) blz: 632. 
de heer van Dalenbroek vorderde de schout, dat "den gedetineerden en beclaegden om de bij hem begaene misdaeden gestraft sal worden naer recht en justitie, gelijck dergelijeke misdadige behooren gestraft te worden, anderen ten exempel, of met alsulcke pene als een eersaeme gerichte sal bevinden te behooren, ende dat den gedetineerden en beclaegden sal worden gecondemneerd in de costen en misen van justitie vel alias etc." Bovendien verzocht hij, dat de gedetineerde bimnen vierentwintig uur van antwoord zou moeten dienen in scriptis en dat hem ten dien einde ex officio een "bediende" d.w.z. een rechtskundig adviseur, zou worden toegewezen, en dat deze het patrocinium - de verdediging - prompt zou moeten aanvaarden.

De schepenen van Maasniel wezen vervolgens de Roermondse notaris Dionysii ${ }^{30}$ als "bediende" of procureur van Laurent Timmermans aan en droegen hem op binnen vierentwintig uur schriftelijk van antwoord te dienen nisi causam, d.w.z. tenzij hij geldige redenen zou hebben om de bediening niet te aanvaarden. Na diens aanvankelijke weigering, besloten de schepenen van Maasniel op 23 april hem te verplichten de verdediging van Laurent Timmermans te aanvaarden. $\mathrm{Zij}$ garandeerden hem de betaling van diens "ordinaire als extraordinaire devoiren in dese crimineele saacke te doen", alsmede van de kosten van de consultaties met advocaten, indien hij zulks noodzakelijk zou achten.

Op 24 april verklaarde procureur Dionysii zich bereid de verdediging van Laurent Timmermans op zich te nemen en verzocht acces tot de beklaagde om diens verdediging voor te bereiden. Procureur Schreurs verklaarde zich hiermee namens de schout van Dalenbroek akkoord, mits Dionysii de schout telkens op de hoogte zou stellen van de redenen, waarom hij zijn cliënt zou willen spreken. Voor Dionysii was deze voorwaturde niet acceptabel, ondat de schout "des gedletineerdens tegensparthije [is], aen wie hij sijn geheim niet en moet noch en mag reveleren".

Na enkele malen uitstel, diende Dionysii op 30 april van voorlopig antwoord en verzocht kopie van de personele responderinge. Procureur Schreurs verzocht namens de schout kopie van antwoord. Op 1 mei verzocht procureur Dionysii,

so Edmund Dionysii, notaris en procureur, bewoonde in de weede helft van de achtiende eeuw her zgn. Gothische Huis alan de Brugstrat te Roemond. Zijn zoon Franciscus Dionysi werd in 1798 griffier van het Tribunal correctionnel aldar. M.K.J. Smeets, Bewoners van het Gothisch Huis in de Brugstrat te Roemond, in: De Matsgouw 63 (1943) blz. 21.Van hem zijn protocollen overgeleverd wit de jaren 17631793; cfr. F.L. Hartong, Register der protocollen wathotarissen in Nederiand, ra.p. blz. 64 en bl2. 500; zie ook Verslagen omtrent 's Rijks oude Archieven $34(1911) \mathrm{bl \alpha}$. 631 . 
dat de klager binnen vierentwintig utur van repliek zou dienen. Dit geschiedde na enig uitstel op 6 mei. In zijn repliek stelde procureur Schreurs namens de schout vast, dat Laurent Timmermans een aantal van de ten laste gelegde feiten bekende maar andere punten bleef ontkennen. Hij verzocht daarom admissie ten thown. Procureur Dionyssii stemde daarmee in, en stelde voor 11 en 12 mei daartoe aan te wijzen.

Op $\|$ mei werden enige getuigen, die in het kader van het wooronderzoek door de sehout ten overstaan van schepencommissarissen waren gehoord, "des meineedts gewaerschouwt, vereedt". Hen werd vervolgens hun eerdere verklaring voorgehouden en gevraagd of $z i j$ daarbij onder ede wilden persisteren. Tijdens deze zittingsdag ontstond er een debat tussen beide procureurs over de vraag, of de procureur van de beklaagde op voorhand inzage zou mogen hebben van de verklaringen, die tevoren door getuigen te Wassenberg en Dahlen in het hertogdom Gulik waren afgelegd, aangezien de scholtis voornemens was requisitoriaalbrieven te verzoeken, ten einde die getuigen thans door de Gulikse rechter onder ede te laten verhoren. Procureur Dionysii was van mening, dat de requisitoriaalbrieven gedurende zes dagen opgehouden zouden moeren worden, ten einde hem in de gelegenheid te stellen contrarogatoria op te stellen, opdat die tegelijkertijd beantwoord zouden kunnen worden. De schepenen van Maasniel hebben in dit debat niet onmiddellijk uitspraak gedaan, maar eerst rechtsgeleerd advies ingewonnen bij twee Roemondse advocaten, J.B. Stuers ${ }^{51}$ en F.J.A. Ramaeckers. ${ }^{52}$ Deze onpartijdige adviseurs formuleerden op 20 mei een concept-decreet, conform de eis van procureur Dionysii.

Ter zitting van 25 mei legde procureur Schreurs een aantal onder ede bevestigde getuigenverklaringen over, alsmede de interrogatoria en daarop gevolgde verklaringen van de door de gerechten van Wassenberg en Dahlen op zijn verzoek verhoorde getuigen. Hij stelde zich echter op het standpunt, dat procureur Dionysii wel kopie zou mogen hebben van de interrogatoria, maar niet van de deposities der getuigen. Zijns inziens zou de bediende van de

"I Jean Buptist Stuers, advocaat te Roemond, werd in 1778 worstelijk hofrad te Thom, rad-fiscall in het Thomse Hof wan Appel en commissaris-deciseur te Neeroeteren; in 1779 werd hij benoemd tot momboir of rad-fisctal van het Hof van Gelre. Cfr. A.M. JA. Berkens. Het Niewwe Landredt wan Thorn. Verticht absolutisme en codificatie onder het bewind van de vorstinmabdis Maria Cunegonda van Saksen (17761794), in: Honoris Catisa. Opstellen angeboden aan profmr. O. Mooman van Kappen, Nijmegen 1999 (Rechtshistorische Reeks GNI d. 42), ta.p. blz.'9

3 Frans Jean Albert Ramaeckers was schepen wan Roermond 1772-1789. CFr. G.H.A. Vemer. De schepener, radswerwanten en payburgemeesters van Roermond sedert 1637, in: PSHAL 124(1988) blz. 145-200, ta.p. blz. 151. 
beklaagde geen inzage van de antwoorden behoeven on contratrogatoria te Kumen opstellen. Deze kwestie werd door de schepenen wan Mabsniel opneuw aan een onpartijdig adviseur voorgelegd, die op 26 mei adviseerde ten gunste van procureur Dionysii. De schout zou hem kopie moeten verlenen van interrogatoria en deposities; bovendien zou hem zes dagen witstel moeten worden gegeven om contrarogatorièn op te stellen. De schepenen van Matusniel deden op dezelfide dag conform uitsprata.

Hiema werd de procedure tijdelijk opgeschort, doordat op 4 jun procureur Schreurs namens de schout van Dalen broek "natedere additièn totte prowisionele teyten van belastinge" overlegde, met het verzoek, dat de beklangde Laurens Timermans daarover semotis advocato et procuratore, d.w.z. zonder [bijstand van] acvocaat of procureur ten overstaan van schepen-commissarissen zou. worden verhoord, in feite dus een tengkeer naar de eerste fase van het proces; welk verzoek door de schepenen van Maasniel werd toegestaan. Op 6 juni werden de "naerdere additien" opnieuw ingediend, maar nu als "naedere provisionele aaenclachte" "met het verzoek de beklaagde daarop binnen vierentwintig uur in scriptis te laten antwoorden. Hierop diende procureur Dionysii - na enige uitstel - op 10 juni provisioneel van antwoord. Op 12 juni repliceerde procureur Schreurs, dat wit het overgelegde antwoond bleek, dat de beklaagde Laurens Timmermans "in negativis persisteert", en werzocht opnieuw toelating ten toon. Op 15 jumi legde procureur Schreurs dientengevolge opnieuw interrogatoria over met her verzoek requisitoriaalbrieven te zenden naar de heerlijkheld Elmpt, om aldaar een bedlegerige getuige onder ede te mogen doen verhoren. Op 27 juni daarna legde procureur Schreurs de inmiddels ontvangen litteralen thoon aan de schepenen over, met het verzoek, dat de inhoud datrvan tot aan de vocale thoom "magh blijven gesecreteert". De klagers zagen van verder bewijs af en verzochten, dat de procureur van de beklaagde van tegenbewijs zou dienen. Op I juli renuncieerde procureur Dionysil voorlopig van tegenbewijs en verzocht opening en kopie van de literale en vocale thoon. Dit werd hem door het gericht toegestaan. Daammee $\mathrm{kwam}$ het proces in het stadium van het reprocheren (wraken) der getuigen, waartoe de klager procureur Dionysii op 7 juli uitnodigde. Na enig uitstel, diende deze op 17 juli van reprochen, waarna procureur Schreurs op 21 juli van salwatién diende.

Hoewel de criminele rol na deze datum geen inschrijuingen meer bevat over het proces tegen Laurent Timmemans, moeten er in de maand juli nog ten minste twee zittingen zijn geweest, op 29 juli en op 3 . jull. Uit een in her procesdossier bewaard gebleven rechtsgeleerd advies, kan worden opgemaakt. dat er op 29 juli wederom discussie is geweest over de vraag of procureur Dionysii recht had op kopie van de preparatoire intomaties zoals door de 
scholtis ingewonnen. Het advies van de advocaat J.B. Stuers luidde wederom bevestigend. Vermoedelijk is het proces dama verdaagd in verband met de zomervalkantie ${ }^{33}$

In de loop van augustus - de exacte datum blijkt niet uit het rolregister of uit het procesdossier - heeft de schout, ten einde het bewijs te completeren, een decreet van tortuur verzocht; hetgeen hem op 31 augustus 1778 , na completering van de schepenbank, is verleend, zonder dat de schepenen het nodig hadden geoordeeld hierower rechtsgeleerd advies in te winnen. ${ }^{54}$ Deze nalatigheid heeft de procureur Dionysii aangegrepen om zich bij de Soevereine Raad te Roermond over de gang van zaken te beklagen, opschorting van het decreet van tortuur en evocatie van het proces te verzoeken.

\section{APPEL TOT NLETIGVERKARNG}

In het rekwest dat procureur Dionysii namens Laurent Timmermans bij de Soevereine Raad te Roermond indiende word gesteld, dat de schout van Dalenbroek er niet in was geslaagd door middel van getuigen de te laste gelegde feiten - voor zover niet wrijwillig bekend - te bewijzen en dat soms zelfs niet eens vast stond, dat clie strafbare feiten inderdaad waren gepleegd. De schout werd er vervolgens van beschuldigd, dat hij desondanks een decreet van scherper examinatie had verzocht "om alsoo des suppliants confessie per fas et nefas door de onlijdelijcke pijne der torture te extorqueren ende alsoo wederrechtelijck ... te sanieren het defect van bewijs ..." Ondanks verzet van de beklaagde, hadden de schepenen van Maasniel, zonder hierover verder rechtsgeleerd advies in te winnen, de beklaagde inderdaad tot de tortuur veroordeeld. Dit decreet was nar de mening van beklaagde niet alleen wederrechtelijk, maar ook nietig.

Ter adstructie van het wederrechtelijk karakter van het decreet voerde procureur Dionysil de wolgende argumenten aan: ten eerste stelde hij, dat toepassing van

5a Volgens GLS 2. art. 4 hepen de gerechtelike vakanties van ach dagen wón tot acht daget nu pasen en punksteren, wan 20 juli tot 1 september en van 20 december rot 14 janturi. Op feesthugen en jarmarkten werden ook geen rechtszitingen - behoudens markigedingen - ge gouden.

s De tekst wan het decreet Huidde alls volge: "t Gericht met assumptie van enen onpartijdigen schepen ayt den gerichte wan Swalmen en Asselt, gesten de stukken in sake gevlooten. condemneert den gedetneerden en beclaegden ter bancke ofte scherpe examinatie. Acrum op den raedthuyse bimen Maesnell den 31 , atgust 1778 ; onderstondt ter ordonnantie elc.; was onderteeckent J.B. Haex" (cfr. decreet van 31 augustus $1778 \mathrm{in} \mathrm{RAL,} \mathrm{Hof} \mathrm{van} \mathrm{Gelre,} \mathrm{inv.nr.} \mathrm{61,} \mathrm{fol} \mathrm{115 \% .}$ 
de tortuur strijdig was met de intenties van keizenin Maria Theresia, die in februari 1776 de tortur in de Habsburgse erflanden lad afschaft en de doodstraf had beperkt tot gruwelijke delioten. ${ }^{55}$ Hj ontleende deze kentis aan de Observations sur des matieres de jumispradence criminelle van Papil Risi. waarvan in 1776 te Maastricht een Franse vertaling uit het Latin was werschenen. 56 Vervolgens merkte hij met een verwighing naar Digestan 48.18.1.1 op, dat als de tortuir nog geoorloofd zou zijn, dat deze enkel nog toepasbaar zou zijn in die gevallen, dat het bewijs tegen de beklangde zodang compleet was, dat slechts diens bekentenis daaraan nog ontbrak. Hij citeerde in dit verband de opmerkingen van Augustinus over de beperkingen van de menselijke rechtsprak in diens De Civitate Dei, waar deze kerkvader opmerkt. dat de onwetendheid van de rechter bij de toepassing van de tortuur valk het ongeluk wordt van een onschuldige. ${ }^{57}$ Verder verwees hij naar Loovens' Practycke, sriel en de maniene wan procederen in Haere Majesteyts Somvereynen Raede van Brabant ${ }^{58}$ Julius Clarus' Practica crimmalis" Paulus Christinaeus' Commentaria in leges municipales Mechlinienses ${ }^{60}$, Joos de

5s Op 3 februan 1776 werd de tortuur afgeschaft in alle Oostenrijkse erflanden met inbegrip van het Banaat van Temesvar en Galicit. J. Monballyu, Vergiftiging, tortuur en beroep tot nietigverklaring in de kasselrij leper: het proces Pietter Geloen. 1785 1786, in: R. Opsommer (ed), Van leperse scholen en lenen, schilderijen en criminelen wit velerllei eeuwen, leper 1999, blz. 147-171, t,a.p. blz. 151 .

56 Cr. E. Heynen, Maastrichtse drukken (1552-1816), in: PSHAL 83 (1947) blz. 1-174; PSHAL 84 (1948) blz. 1. 139, nr. 588

57 Augustinus, De civitate dei, XIX, 6; vgl. Aurelius Augustinus, De Stad van God, vertaald en ingeleid door $\mathrm{G}$. Wijdeveld. Amsterdam 1983, bl\%, $949-950$.

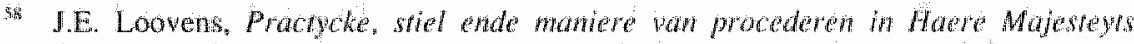
Souvereyen Raede van Braboni, Brussel 1745 . Verwezen word nar de 8 Wander rex

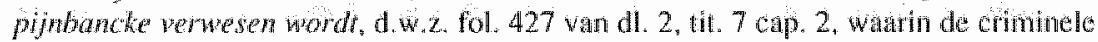
procedure voor subalterne banken wordt behandeld.

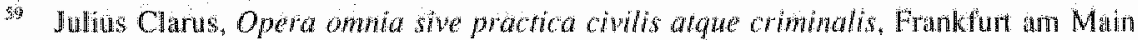
1636, lib. $V, q .64, n .13$. Deze paragraff behandelt de vragg wameer anvijingen voldoende zijn om loepassing van de tortudir te reblutwardigen.

Panlus Christmaeus, In leges municipales eiasden civitatis ac prowinchae commenaha et hotae. Geratipleegd is de vierde editie, Antwerpen 1671. Verwezen wordt natar Tit. 1. art. 7, n. 4. In dit commentaar op art. 7 wan de costumen van Mechelen, warin het de schout wordt verboden zonder consent van de commoignimeesters iemand ter banke te brengen, wordt cen viertal kriteria geformuleerd voor de toepassing tor de tortuur. Volgens het vierde kriteriun dienen de schepenen over voldoende waarschijnlijke anwijzingen te beschikken: Sed quatia ese debean illa indicia. nom porest dar certa doctrina, sed commitritur arbitrio iudicantis. 
Damhouder's Praxisererum criminalium $^{61}$ en naar art 61 van de Criminele Ordonnantre van 5 juli $1570^{62}$. Met instemming citeerde hij vervolgens Digesten 48.18.1.23: men moet niet lichtvaardig zijn vertrouwen stellen in de tortutir, want het is een res fragilis et periculosa et quae veritatem fallat, een onbestendige, gevaalijke en bedrieglijke aangelegenheid. Ten derde nerkte hij op, dat het verteende decreet van tortutur zich niet mocht uitstrekken tol de reeds door zijn client vrijwillige bekende strafbare feiten. Hem in dit stadium van het proces daarover alan een scherp verhoor te onderwerpen, heeft geen meerwaarde, omdal hij deze feiten reeds had toegegeven. Bovendien leverden deze bekentenissen op zich geen grond voor veroordeling op, omdat de schout - in strijd met GLS 375, ant 12 - verzuimd had bewijs te leveren met betreking tot desbetreffende feiten. ${ }^{63}$

Voor de nietigheid van het tussenvonnis voerde Dionysii twee argumenten aan. Ten eerste beriep hij zich op de omstandigheid, dat de schepenbank voor het uitspreken van het tussenvonnis niet op de juiste wijze was gecompleteerd. Het gerecht was niet gecompleteerd met een schepen van de schepenbank van Ool, maar men had een schepen uit de buiten de heerlijkheid Dalenbroek gelegen schepenbank van Swalmen geassumeerd. ${ }^{64}$ Ten tweede werd gesteld, dat de schepenbank had verzuimd rechtsgeleerd advies in te winnen, alvorens verdachte ter tortuur te verwijzen. Deze nalatigheid van de schepenen was in strijd met artikel 43 van het Eeuwig Edict van 1611 , dat voorschrijft, dat niet rechtskundig onderlegde schepenen "in saecken van importancie" geen besluit mogen nemen, alvorens het advies ingewonnen te hebben van "geleerde luyden,

3) Josse de Damhouder, Pravis rem criminahm, Anwerpen 1601. Geradplecgd werd de thesimile-editie Aalen 1978. Verwezen werd nati Cap. 54, n. 9: Ex indichis:

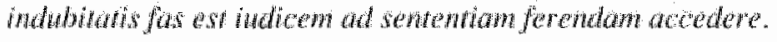

th2 Art $61 \mathrm{CO}$ bestempelde de gewoonte temand to de pijnbunk te veroordelen op grond van de verklwning wan bén gretuige, zonder onderscheid te maken met betrekking tot de aud wan het delict of de kw aliteit van de persoon, tot corrupted.

6.3 Ter adsinche beroept procureur Dionysin zich bovendien op Risi., cap. 2 , fol. 45 e.w.

we Matrichtse rehter ll. de Wit, die in 1916 een artikel publicerde over misstanden in de rechtspratk in Limburg ten thide van het ancien regine, vermeldde zonder bronvermelding - cen analoog gewal, warin de schepenbank wan SwalmenAsselt geompteteerd werd met een andifate schepen uit de schepenbank van Masnich. Partiju namen hermee gen genoeger en beklangden zich bi de Soevereine Rata, die het proces evoceerde. Cfr. I.J. de Wit Inwendige toestanden in enkele heerlijkheden, man wooral in de wrije njoksheerbjkheid Rijokholl in de $17 \mathrm{e}$ en $18 \mathrm{e}$

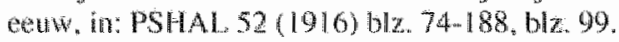


geverseert in de practijcke" en gaf in de ogen van procureur Dionysii blijk van "al te grote animositeit en partialiteit tegen de arme en bedruckte suppliant". Gelet op de wederrechtelijkheid en de nietigheid van het gewraakte decreet, verzocht procureur Dionysii het Hof recursus ad principem, danwel revisie van het tussenvonnis, met opschorting van de tenuitvoerlegging en evocatie van de zaak ten principale.

Bij apostille van 4 september 1778 besloten kanselier en raden het verzoekschrift aan de schepenen van Dalenbroek te communiceren, en de tenuitvoerlegging van het decreet van tortuur voorlopig op te schorten.

\section{VERZOEK TOT STAFOMZETTING}

Terwijl kanselier en raden nog in afwachting waren van de reactie van de schout van Dalenbroek op het bezwaarschrift wan procureur Dionysii, ontvingen zij op 17 september van de Geheime Raad een verzoekschrift van de naaste verwanten van Laurent Timmermans, waarbij deze omzetting van diens eventuele lijfstraf in gevangenisstraf verzochten, voor advies. ${ }^{65} \mathrm{Zij}$ legden dit verzoekschrift, zoals gebruikelijk, voor aan de schout van Dalenbroek ter fine van commentaar. Deze reageerde op 2 october 1778. Hij merkte op, dat het verzoekschrift was ingediend op naam van de naaste verwanten, zonder dat deze met name werden genoemd. Hij stelde zich op het standpunt, dat hun namen door procureur Dionysii, die namens hen zei op te treden, zouden moeten worden geproduceerd. Hij was van mening, dat het doel, dat een officier nastreeft d.m.v. een criminele procedure, namelijk het "besorgen van de algemene ruste" inderdaad zou kunnen worden bereikt indien het verzoek van opsluiting in een correctiehuis zou worden gehonoreerd, mits Laurtent Timmermans levenslang zou worden opgesloten, en hij de namen van zijn complicen zou prijs geven.

Uit het feit dat men hangende het proces een verzoekschrift had ingediend bij de Geheime Raad, bleek zijns inziens, dat zelfs zijn̈ pröcureur reeds van zijn schuld was overtuigd. Hij veronderstelde, dat men het verzoekschrift bij de Geheime Raad had ingediend, in de veronderstelling, dat kanselier en raden in het verzoek tot ongedaanmaking van het decreet van tortuur en evocatie van het proces niet zouden willen treden.

65. M.b.t. gratieverlening door de Geheime Ratad in de achttiende ceuw, zie: Cl. Bruneel, Le droit penal dans les Pays-Bas autrichiens: les hesitations de la pratique (17501795), in: R.Moriter, H. Hasquin, Eudes sur le XVIre siècle 13(1986) b/2. $35-66$. 
De scholtis sprak er zijn verbazing over uil, dat de naaste verwanten zolang hadden gewacht met het indienen van het gratieverzoek. Bovendien was hij van mening, dat zij zich met hun verzoek niet tot de Geheime Raad hadden hoeven te wenden, maar dat zij het net zo goed bij her Hof te Roermond hadden kunnen doen ("bij desen souverainen hove van gratie en justitie"). ${ }^{\text {ti }}$ Zij zouden zich daardoor hoge kosten hebben bespaard. Het verbaasde hem tenslotte, dat in het verzoekschrift nergens werd gesproken van refusie van kosten, hoewel dat een gebruikelijke conditie was bij het verlenen van dergelijke graties.

\section{DE CASUS LAURENT TIMMERMANS IN RELATIE TOT HERVORMUNG VAN HET STRAFRECHT}

Kanselier en raden grepen het rapport over het gratieverzoek van Laurent Timmermans aan om hun opvattingen over door hen noodzakelijk geachte hervormingen van straffecht en strafprocestecht, zoals zij die in juni 1766 reeds in een wetgevingsadvies uiteengezet hadden, nogmaals onder de aandacht van de centrale regering te brengen. ${ }^{67}$

In hun advies gaven zij eerst een kort overzicht van de delicten; waarvan Laurent Timmermans werd beschuldigd: oplichting, domestieke diefstal, negen andere diefstallen, waarvan drie met braak, twee maal ontsnapping uit een gevangenis, eenmaal vreemde krijgsdienst en eenmaal werving ten behoeve van vreende krijgsdienst. Op het eerste gezicht een indrukwekkende lijst. Volgens hen hadden vooral de laatste twee beschuldigingen weinig om het lijf. Laurent Timmermans was niet vrijwillig in Pruisische dienst getreden, maar geronseld; bovendien bevond hij zich op dat moment niet in de Oostenrijkse Nederlanden; werving ten behoeve van de keurvorst van de Palts viel niet te bewijzen, ondat degene die hij zou hebben geronseld geen medewerking wilde verlenen. Kanselier en rader stelden daarom voor, zich te concentreren op de

w De schoul wan Dalenbroel is er kennelijk net van op de hoogte, dat de Geheme Ras in het kader van de zan. querelle des octrois in 1776 an kansellier en raden de bevoegdheid had ontnomen, zelf dergelijke graties ve verlenen: Cfr. A.M.J.A. Berkvens, "In wesen sal het "Tractaet van Venlo onderlatden werden" .... in: F. Keverling Buis* man, ea. (red.). Verdrag en tractatat van Venlo. Herdenkingsbundel, 1543-1993, Hilversum 1993 (Werken "Gelie", no. 43\%, blz. 153-170, ta.p. blz. 66.

67 Voor het advits wan 1766 zie: A.M.J.A. Berkwens, Hervorming wan strafrech en strafprocesrecht in de Zuidelijke Nederlanden in de tweede helft van de achtriende eeuw, in: A.MJ.A. Berkvens e a. (red.), "Flitich erforscht und gecolligeen ... Opstellen over Limburgse rechtsgeschiedenis, Mastricht 1995, blz. 137-171, t.a.p. blz. $141-150$ 
overgebleven zeven delicten. Eerst wilden zij onderzoeken, wat een gepaste straf zou zijn voor de oplichting en domestieke diefstal, die Laurent Timmermans reeds bij herhaling had bekend. Vervolgens wilden zij nagaan of de overige diefstallen - die hij stelselmatig had ontkend - van dien aard waren, dat toepassing van de pijnbank geoorloofd zou zijn.

Alvorens daartoe over te gaan herhaalden zij in essentie hun bezwaren tegen de pijnbank, zoals zij die in 1766 ook al hadden geformuleerd. Naar hun mening stond de nutteloosheid, ontoereikendheid en gruwelijkheid van de barbaarse gewoonte mensen op de pijnbank te leggen om het bewijs te completeren tegen verdachten die men anderszins niet zou kunnen veroordelen, als een paal boven water. Zij wezen er op, dat men reeds in diverse staten de tortuur had afgeschaft, zonder dat zich daar de ongemakken hadden voorgedaan, die tegenstanders van de afschaffing van de tortuur vreesclen. In de gegeven situatie echter, dat de tortuur in de Oostenrijkse Nederlanden nog niet was afgeschaft, diende men er een zeer spaarzaam gebruik van te maken en daarbij de grootste zorgvuldigheid in acht te nemen. De volgende vier punten waren daarbij essentieel:

- Tortuur kan alleen worden toegepast, indien de doodstraf voor het delict in kwestie mogelijk is. Kanselier en raden geven aldus een engere interpretatie aan de bepaling, dat tortuur alleen geoorloofd is in het geval zeer grove en lelijke misdaden. ${ }^{68}$

- Indien aan deze voorwaarde is voldaan, moet worden vastgesteld dat het delict inderdaad is gepleegd.

- Indien het corpus delicti is geverifieerd, dan dient men eerst met gewone middelen bewijs te leveren; slechts in laatste instantie mag men zijn toevlucht nemen tot de pijnbank. ${ }^{69}$

- In dat geval moeten er reeds zoveel aanwijzingen en bewijzen voorliggen, dat de schuld van de verdachte vrijwel buiten twijfel is. Men mag dit laatste niet lichtvaardig aannemen: "pour un delit incertain on ne doit pas faire souffrir à l' accusé une peine certaine".

Toepassing van deze beslisregels op de casus Laurent Timmermans laat zien, dat in twee van de negen gevallen van diefstal er mogelijk sprake is van voldoende aanwijzingen om een verwijzing naar de pijnbank te rechtvaardigen: de verdachte was bij zijn aanhouding in het bezit van enkele gestolen voorwerpen, waarvan hij voorgaf, dat hij ze van een handelaar had gekocht.

6ii. Clr. GLS 380, ant. 3

(5) Dezerplichting vindt men als zodanig niet in GLS 380 , art. 1-3. 
Zijn slechte reputatie en zijn bekentenis van andere delicten versterkten de kracht wan de aanwijzingen. In de overige zeven gevallen was er zo weinig bewijs voorhanden, dat kanselier en raden zich afvroegen, hoe de schout van Dalenbroek het in $z$ "n hoofd had kunnen halen de verdachte hiervoor in stat van beschuldiging te stellen.

Waren de diefstallen, waarvan het corpus delich was geverifieerd, van zodanige dard, dat men de verdachte daarvoor ter dood zou kunnen veroordelen? Deze vraag moest worden beantwoord aan de hand van de Geiderse Land- en Stadsrechten. Volgens het statutaire recht van het Overk wartier verdiende een dief de galg, tenzij de rechter van oordeel was, dat wegens de geringheid wan de diefstal, of om andere moverende redenen, met een mindere straf volstaan kon worden. Kanselier en raden stelden zich op het standpunt; dat het humaan en billijk was niet gekwalificeerde diefstallen onder deze uitzondering te begrijpen. Immers de natuurlijke billijkheid veronderstelt evenredigheid tussen delict en straf. Afweging van de waarde wan een mensenteven tegen de waarde van een gestolen goed, diende vanzelfsprekend in het voordeel van het mensenleven uit te vallen. Dit gold naar het gevoelen van kanselier en raden ook in her geval van herhaalde diefstal. $Z$ ij bestreden de opvatting, dat men in dergelijke gevallen op grond van de onverbeterlijkheid wan de misdadiger de doodstraf zou mogen opleggen. Als men de mening was toegedaan, dat straffen niet enkel dienden om de veiligheid der burgers te verzekeren, maar ook om mensen te verbeteren, dan kon de doodstraf slechts als een ultimum remedium worden gezien. ${ }^{70}$

Zij concludeerden derhalve, dat de verdachte Laurent Timmermans vanwege de twee hiervoor besproken diefstallen niet ter dood veroordeeld zou kunnen worden, en derhalve - op grond van de hiervoor geformuleerde beslisiegels - ook niet ter tortuur gesteld zou mogen worden.

Vervolgens onderzochten kanselier en raden, of de verdachte wegens de door hem toegegeven oplichting en domestieke diefstal ter dood veroordeeld zou kunnen worclen. ${ }^{71}$ Laurent Timmermans had deze delicten in 1772 gepleegd in de Meierij van "s Hertogenbosch. Volgens kanselier en raden was het onwaarschijnlijk, dat Laurent Timmermans vanwege het ene of het andere

Cr. het advics, dat kanselier en raden in 1777 hebben uitgebracht terzake van de bestraffing van gekwalificeerde diefsal, in: A.M.J.A. Berkwens, Hervorming wan strafrech en simaforocesecht, biz. $168-170$.

7) Cri, het advies terzake wan de bestrafing van domestieke diefstal, dat kanselier en raden in 1766 hebben uitgebrach, in: A.M.J.A. Berkvens, fferwoming van strafrecht en strafprocesrech, bli, $150-154$. 
delict aldaar met de dood gestraft zou zijn. Volgens Antonius Matthaeus $D e$ crimmibus $^{72}$ werd diefstal in Holland niet met de dood gestraft; volgens Groenewegen van der Made en Joannes Voet werd de lex Connelia de falsis in Holland niet toegepast, evenmin als het plakaat van Karel $V$ d.d. 30 januari 1545, maar werd de strafmaat overgelaten aan de discretie van de rechter, zoals ook blijkt bij van Zurck, die in zijn Codex Batavus meerdere voorbeelden van lichtere straffen vermeldt. ${ }^{73}$

Kanselier en raden stelden zich op het standpunt dat het blote feit, dat de verdachte onderdaan was van de Oostenrijkse Nederlanden en binnen de Oostenrijkse Nederlanden werd berecht niet eraan in de weg stond, dat hij moest worden berecht volgens de wetten en gewoonten die golden ter plaatse waar het delict was gepleegd. De strengere wetgeving van de Oostenrijkse Nederlanden moest derhalve buiten toepassing worden gelaten. Omdat aldus ook deze delicten niet met de dood gestraft zouden kunnen worden, was ook hier niet voldaan aan de vereisten om tot een veroordeling tot de tortuur te kunnen komen.

Over de vorm van het tussenvonnis van de schepenbank Maasniel merkten kanselier en raden op, dat de verwijzing naar de tortuur wegens het ontbreken van enigerlei vorm van instructie met betrekking tot de te stellen vragen, zodanig waag was, dat de pijnlijke examinatie zich zou kunnen uitstrekken tot alle strafbare feiten die de officier ten laste zou willen leggen. ${ }^{74}$ Zij vroegen

72 Ant. Mathaeus, De Criminibus ad lib. XLVII et XLVIII Dig. commentarius, Trajectum ad Rhenum 1644, Lib. 47, tit. 1, cap. 3, n. 4 behandelt de vragg An furtum mag-

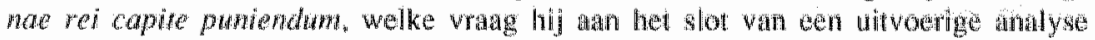
onlkennend beantwoord" ("Furem magnate rei suspendendum nulllo modo esse").

${ }^{3}$ Crr. Simon Groenewegen van der Made. Tracuatus de logibus abrogatis et inusitatis in Hollandia, Ansterdam 1669, commentad bij Instirtern IV, 18,7. Groenewegen vath der Mate merkt in zijn commentar over de falsi poena juris chilis op. dat heh edick van Karel $Y$ van 30 januari 1545 (Groot Placcatboek d1. 1, fol. 383), dat voor derge-

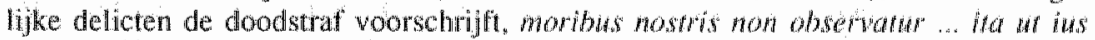
chile Romanorum fere in unum revoratur videath. Van dezelfte strekking is het Commentar van Johanies Voet, Commenturius ad Pandectas, Hagae Comitis, 1734, dI. II, in zijn commentaar op Digesten 47, 10. Zie ook Eduard van Zurck. Codex Batavus, 3e druk, Rotterdam 1738, s.v. folsarisen, wadr dezo opmerki, dat het plak kaat van 1545 weliswar de doodstraf voorschriff, doch "om de oneindige veale soorten wan falsiteiten is de straf arbitrair; doch wegens een gequalificeent falsum geeseling, ban en confiscatis gebruikelijk ..."

7. De tekst van het decreet luidde als volg: "I Gericht met assumptie van eenen onpartijdigen schepen uyt den gerichte van Swalmen en Asselt, gerien de stukken in satke gevlooten, condemneert den gedetimeerden en bechegden ter bancke ofte scherpe 
zich af, of de schepenbank Maasniel zich wilde scharen in het kamp van die rigide criminalisten, die meenden, dat men een misdadiger die een bekentenis heeft afgelegd op de pijnbank mocht ondervragen over eventuele andere misdaden die hil ook nog zou kunnen hebben gepleegd. Een opvatting die zij met een beroep op de Observations sur la torture van Papil Risi verwierpen. Bovendien waren zij buitengewoon verbatsd over het feit, dat de schepenbank Maasniel de verdachte Laurent Timmermans bij tussenvonnis tot de pijnbank had durven veroordelen, zonder daarover rechtsgeleerde adviseurs te raadplegen. De artikelen 57 en 58 van de Criminele Ordonnantie van 1570 , ant. 38 vain de Ordonnantie op de Stijl en art. 43 van het Eeuwig Edict van 1611 verplichten hen ertoe rechtsgeleerd advies in te winnen "dans une matière si delicate, si arbitraire et si importante, qu' est celle de la torture qui emporte ordinairement la condemnation a la mont." Zij verbonden aan deze ernstige fouten de conclusie, dat het zeer wenselijk zou zijn de criminele rechtspraak te onttrekken aan dorpsschepenen, of hen tenminste te verplichten hun vonnissen the laten toetsen door de Soevereine Raad, welke oplossing zij - getrouw aan hun advies uit 1766 - nog altijd beschouwden als het beste middel om misslagen van onwetende rechters te voorkomen, die ondanks hun kennelijke onkunde aanspraak bleven maken op het privilege in criminele zaken recht te spreken, zonder appel of revisie.

Nadat zij zich aldus op vernietigende wijze hadden uitgelaten over de criminele procedure, zoals door de schepenbank van Maasniel gevoerd, kwamen kanselier en raden toe aan behandeling van de vraag, of de Geheime Raad zou moeten instemmen met het verzoek van de naaste verwanten van Laurent Timmermans tot omzetting van een eventuele dood- of lijfstraf in gevangenisstraf. Dit verzoek werd door kanselier en raden zonder meer ondersteund. Zij waren van mening, dat een dergelijke straf eerder paste bij de aard van de misdrijven, warvan Laurent Timmermans werd beschuldigd, dan willekeurig welke andere lijfstraf. Zij grepen de gelegenheid aan, ervoor te pleiten, dat in Oostenrijks Opper-Gelre een eigen gevangenis zou worden opgericht, danwel, dat er afspraken zouden worden gemaakt met Brabant of Vlaanderen, om veroordeelde delinquenten hun straf daar te laten uitzitten tegen een vaste vergoeding per hoofd, danwel tegen een jaarlijkse vaste bijdrage. Zij herinnerden de Geheime Raad eraan, dat zij reeds eerder hadden aangetoond, dat gevangenissen het meest geschikt waren om lijfstraffen, geseling en

examinatie. Actum op den raedhuyse binnen Maesniell den 31, august 1778; onderstondt ter ordonmantie etc; was onderteeckent J.B. Haex." (afschrift in: RAL, Hof van Gelre, inw ar. 61, fol. 115) 
verbanning te vervangen; dat gevangenisstraf tegemoet $k$ wam tan de bezwaren tegen afschaffing van de tortuur en een reeel middel was ter bestraffing van bedelarij en landloperij, waardoor men kon woorkomen, dat rechters genoodzaakt zouden zijn recidivisten zelfs wegens eenvoudige diefstal ter dood te veroordelen. ${ }^{75}$

Uit het rapport van de officier van de heerlijkheid Dalenbroek concludeerden zij, dat deze ook met het verzoek zou kunnen instemmen, mits aan een viertal voorwaarden zou zijn voldaan. Ten eerste eiste hij dat de namen van de naaste verwanten die het verzoek hadden gedaan bekend gemaakt zouden worden; ten tweede, dat Laurent Timmermans gedwongen zou worden de namen van zijn medeplichtigen bekend te maken; ten derde, dat de verwanten de kosten van de criminele procedure zouden vergoeden; en tenslotte, dat Laurent Timmermans levenslang zou worden opgesloten.

Kanselier en raden wezen de eerste drie voorwaarden van de hand. De eerste voorwaarde strekte slechts tot bevrediging van de nieuwsierigheid van de officier. Aan de tweede voorwaarde kon nier worden voldaan, zonder Laurent Timmermans op de pijnbank te leggen. Bovendien was het twijfelachtig, dat hij überhaupt medeplichtigen had gehad. De derde voorwarde wezen zij als buitengewoon hard en onredelijk van de hand, aangezien de verwanten wan Laurent Timmermans de aanzienlijke kosten van de levenslange detentie zouden moeten dragen. $\mathrm{Zij}$ konden echter instemmen met de vierde voorwaarde, die hen voorkwam "tres juste" te zijn.

\section{STRAFOMZETTING EN UITVOERINGSPERIKELLEN}

Gelet op het positief advies van kanselier en raden, besloot de Geheime Raad, in januari 1779 , bij wijze van gratie de gevraagde strafomzetting te verlenen, mits Laurent Timmermans op kosten van zijn verwanten gedurende vifftien jaar zou worden opgesloten in een verbeterhuis en diens verwanten de kosten van de criminele procedure zouden betalen. Volgens de toenmalige gebruiken, had een dergelijke gratie geen directe werking. Een dergelijke beschikking diende eerst door de begunstigde tegen betaling van kosten te worden gelicht bij de Audièntie en vervolgens te worden geïnterineerd of bevestigd door het gewestelijk justitiehof.

75 Cfr. het nader advies over de afschaffing vath de tortur en de optichting wan vabeterWuizer, dat kanselier en raden in 1771 hebben wigebracht, im: A.M.J.A. Berkyens, Hervoming van strafrecht en strafprocesrech, bl $z, 154-156$ 
Bij brief van 14 januari 1779 berichte een commies van de agent d' Otrenge, die in Brussel als lobbyist bij de Geheime Raad ten gunste van de verwanten van Laurent Timmermans had geintervenieerd, dat de Geheime Raad weliswaar de gevraagde gratie had verleend, maar dat de beschikking pas zou worden afgegeven, zodra de verwanten reële cautie zouden hebben gesteld voor de kosten van levensonderboud gedurende de vijftien jaar van diens detentie, te vermeerderen met 68 gulden, 14 stuiver en 6 duiten wegens expeditiekosten. ${ }^{26}$ De verwanten van Laurent Timmermans waren echter niet zo bemiddeld, dat zij in staat waren zowel de kosten van de detentie, als de kosten van de criminele procedure te voldoen. Er ontspon zich vervolgens een briefwisseling tussen procureur Dionysil en agent d' Otrenge, om te bezien of de voonwaarden konden worden verzacht. Uit deze briefwisseling blijkt, dat de verwanten van Laurent Timmermans vrij waren in de keuze van het correctiehuis waar men hem zou opsluiten: te Gent, Brussel, Froidmont; of bij de Ceilebroeders. ${ }^{77}$ Tussen deze inrichtingen bestond kennelijk concurrentie: men kon met de gevangenisdirecteuren onderhandelen over de kosten van levensonderhoud. Indien de kosten van opsluiting voor de familie desondanks te bezwaarlijk zijn, dan zou men kunnen overwegen om Laurent Timmermans dienst te laten nemen in een van de regimenten van de Oostenrijkse Nederlanden: "Si ce Timmermans etoit en etat de servir S.M. et qu' il voulut s' enroller dans l' un ou $l^{\prime}$ autre regiment, l' affaire seroit bientot faite. ${ }^{\text {" }} 78$ Betaling van de proceskosten bleef echter onontkoombaar. ${ }^{79}$

RAL, Hof van Gere, inv. 61 , watol. 154, brief van 14 janwari 1779

RAL. Hof van Gelre, inv. 61, na fol. 154, brief wan 21 januari 1779; met de gevang. enis te Brussel word vernoedelijk die van Vilwoorde bedoeld; de inrichting van de Cellebroders bevond zich eveneens te Brassel.

RAL Hol van Gelre, inv. 61, na fol. 154, brief vam 4 februari 1779, en kapitein wan het regimont van kolonel Donced heef zich bereid verkladid. Lauren Timmemans door een defachement te Roemond te laten ophallen, indien hij bereid was dienst te nemein in diens negiment; volgens Bronesl was het tot 1776 net ongebrukelijk, dat veroordeddo misdadigers in de gelegenheid werd gesteld door dienst te nemen te ontkomen wat de voltrekking wan dig opgelegde lifstaf. Nadien beschouwde men deze pont van stratomzerting als mindar wenseligk, ondat men niet langer de indruk wilde wekken, dat de regimenten van Maria Theresia een wrijplats waren woor misdadigers. Cf. Cl. Bruneel, Le droit penal, biz. 59. Kennelijk is men maderhand weer van deze zionswijze afgestapt. Bij decreet van 23 december 1784 werd an de Raad van Namen toestomming verleend in vookomende gevallen veroordeelden doot inlijving bij een van de regimenten der Oostenrijkse Nederlanden in de gelegenheid te stellen aan de terutwoerlegging van thun lijfstraf re ontkomen (Recueil des Ordonnances des PaysBas, 3 serie. 11 . 15, blz. 219, decreet van 23 december 1784).

RAL, Hof van Gelre, inv. 61 , na fol. 154, Griel wan 13 februari 1779 
Toen de schout van Dalenbroek lucht kreeg van deze problemen, wendde bij zich op 18 februari 1779 tot kanselier en raden met het verzoek, dat zij de verwanten van $\mathbb{L}$ aurent Timmermans zouden verplichten het decreet zo spoedig mogelijk te lichten en ten uitvoer doen leggen. Aangezien Kanselier en raden niet beschikten over een afschrift van de gracieuze beschikking, gelastten zij Herman Lutters - een oom en de inmiddels niet meer anonieme voorman van Laurent Timmermans' verwanten - om de tekst van het besluit binnen één maand over te leggen en intussen een verzoek tot kwijtschelding van de bezwarende voorwaarde in te dienen bij de Geheime Rat:

Toen deze termijn was verlopen, wendde de schout van Dalenbroek zich op 20 april 1779 nogmaals tot kanselier en raden, met een verzoek tot tenuitvoerlegging van de gevangenisstraf. De voortdurende bewaking van Laurent Timmermans in afwachting van diens overbrenging naar een correctiehuis vormde een zware belasting voor de ingezetenen van de heerlijkheid Dalenbroek. Kanselier en raden verleenden de verwanten nogmaals veertien dagen respijt. Indien zij dan nog niet aan de voorwaarden zouden hebben voldaan, zouden zij worden geacht van de verkregen gratie te hebben afgezien.

Op 14 mei liet Herman Lutters, die tot op dat moment alle kosten van het gratieverzoek had gedragen, weten, dat zijn verwanten hem in de steek hadden gelaten, en dat hij daarom niet in staat was de kosten van een nieuw verzoek te dragen, zodat hij zich genoodzaakt zag "de renoncer à la grace que Votre Majesté avoit daigné d' accorder au prisonnier", zoals kanselier en raden op 5 juni 1779 aan de Geheime Raad berichtten.

Voor de schout van Dalenbroek was dit aanleiding om heropening te vragen van het proces en ten uitvoerlegging van hel decreet van 31 augustus 1778 , waarbij Laurent Timmermans ter tortuur was veroordeeld. Naar het gevoelen wan kanselier en raden was dit duidelijk een stap to ver. Zelfs indien de verwanten van Laurent Timmermans afzagen van de verleende gratie, dan bleven nog de bezwaren tegen het decreet van 31 augustus 1778 onverkort gehandhaafd. Kanselier en raden vroegen daarom van de Geheime Raad een uitspraak over de vraag of zij terecht de tenuitvoerlegging van het decreet hadden verboden en de behandeling van de zaak aan zich hebben getrokken. ${ }^{86}$ De Geheime Raad deed in zijn beschikking van 25 augustus 1779 op dit punt geen principiële uitspraak. Men koos er eenvoudig voor Laurent Timmermans uit zijn detentie te ontslaan en hem levenslang te verbannen uit de Oostenrijkse 
Nederlanden. Tevens bepalde men, dat het de schout van Dalenbroek, gezien de kennelike insolventie van de gedetimeerde, vrij zou staan de onkosten op de gebruikeligk wijze te verhalen (op de geërfden wan de heerljkheid Dalenbroek $7 \%$

VIalk voordat het beshit van de Ceheime Rad op 9 september 1779 te Roemond bekend werd, zag de schout van Dalenbroek zich op 6 september genoodzakk kanselier en ralen te berichten, dat Laurent Timmermans er in was geslugd uit het kxsteel van Dalenbroek te ontsnappen, nadat hij met een ijzeren eggetand een gat in de muur had gemakt. Voor kanselier en raden was dit aanleiding om an de Geheime Raad enkele beschouwingen voor te leggen met betrekking lot de vraag, of Laurent Timmemans zich door zijn ontsnapping de hem verleande gratie onwaardig had getoond. In een vrij korzelige reactie, liet de Geheime Raad op 1.5 september 1779 weten, dat kanselier en raden de zaak verder matar moesten laten rusten. ${ }^{8 !}$

Deze rust was $\$$ lechts wan beperkte duur, want op op 21 december 1779 werd Laurent Timmemans opnieuw aangehouden door de sehout van Elmpt, waar hij zich sedert zijn ontsnapping uit het naburige Dalenbroek had schuil gehouden. De schout van Dalenbroek verzocht prompt zijn uivlevering om het proces tegen hem te kunnen woortzetten. Kanselier en raden legden dit verzoek ter line van advies voor aan de momboir J.B. Stuers, dezelfde overigens die in deze zaak als rechtsgeleend advilseur van de schepenen van Maasniel was opgetreden. Deze was van mening dat het het meest in de rede zou liggen, dat kanselier en raden als rechters zouden optreden. Ten aanzien van de strafmaat merkte hij op, dat mede gezien het feit dat Timmemans zich sedert zijn ontsnapping niet aan nieuwe delicten had schuldig gemaakt, het onwarschijnlijk was, dat hij ter dood weroordeeld zou kunnen worden. Wel achite hij de kans op wrak groot. Hij was er darom geen voorstander van hem to verbamen. Hij gal de voorkewr aan opsluiting op een zodanige plats dat Timmermans verder geen schade aan zou kunnen richten en geen nieuwe delicten zou kunnen plegen. Aangezien men in Oostenrijks Opper-Celder net beschikte over een gevangenis en al evenmin over galeien of citadellen, war men delinquenten dwangarbeid kon laten verrichten, stelde hij voor Laurent Timmormans uit te besteden in Pruisen of Gulk, awar men wel gebruik maakte van dwangarbeiders bij de anleg van citadellen.

s. RAL, Hof van Gelre, inv nr. 61, fol. 316-319; over het gevangeniswezen in het herlogdom Gulik, zie: P. Robertz, Die Straftechtspflege am Haupt und Kriminalgericht zu Juhch yon der Karolna bis zur Aufklanng (1540-1744), Jillich 1987 (Veröfent- 
De Geheime Raad repliceerde kort en bondig; dat het decreet van de schepenen van Dalenbroek niet van dien aard was, dat het Hof darin aanleiding had mogen zien, om het proces te evoceren. Zij gelastten bovendien, dat men Laurent Timmermans moest laten genieten van de gratie die hem was toegekend. Dat wil zeggen, dat de schout van Elmpt hem op vrije voeten moest stellen, en dat Laurent Timmermans er zorg voor moest dragen, dat hij voortaan buiten de Oostenrijkse Nederlanden zou blijven. ${ }^{83}$

\section{SLOT}

De casus Laurent Timmermans is een illustratie van de spanning tussen theorie en praktijk van de hervorming van strafrecht en strafprocesrecht in de Oostenrijkse Nederlanden aan de vooravond van de gerechtelijke hervormingen van Jozef II. Zij laat zien, hoe de ideeën van verlichte penalisten doorwerken in de opvattingen van de intellectuele bovenlaag, met name van de academisch geschoolde juristen, die als raadsheren verbonden waren aan de gewestelijke hoven van justitie. Aangeraakt door het gedachtengoed van de Verlichting achtten zij het niet langer toelaatbaar, dat de strafrechtspleging ten plattelande werd overgelaten aan "onverlichte" schepenen, tegen wier vonnissen geen hoger beroep mogelijk was. Hun bezwaren richtten zich met name tegen het feit, dat het aan de arbitraire bevoegdheid van dergelijke onwetende rechters werd overgelaten, verdachten tot de pijnbank te veroordelen, hoewel de toelaatbaarheid van dit onderzoeksmiddel in kringen van verlichte penalisten reeds lang zeer omstreden was.

Om aan deze misstanden een einde te maken achtten $\mathrm{zij}$ - naast verandering wan de strafwetgeving - vooral verandering van de rechterlijke organisatie, gericht op professionalisering van de rechtspraak, noodzakelijk. De juridische adviseurs van Laurent Timmermans hebben de "Zeitgeist" zeer goed aangevoeld, en aldus hun cliënt optimaal laten profiteren van de hervormingsgezindheid van kanselier en raden van de Soevereine Raad te Roermond.

Veel van wat in het kader van de affaire Laurent Timmermans werd bepleit, werd kort nadien door de hervormingen van Jozef II voor korte tijd gerealiseerd.

lichungen des Jülicher Geschichtsverens 10), ta.p. blz. $82-86$.

*. RAL. Hof van Gelre, inv, nr. 62, fol. 46, decreet van 29 december 1779 . 
Nadat reeds eerder in 1784 door middel van interne dienstbevelen de uitvoering van decreten van tortuur aan de goedkeuring van de Geheime Raad was onderworpen $^{34}$, werden door middel van de ordonnanties van 1 januari en 3 aprill 1787 de bestaande rechtbanken in de Nederlanden vervangen door een nieuwe, pyramidaal ingerichte rechterlijke organisatie, bestaande uit éên Soeverein Hof van Justitie, twee Hoven van Appel - te Brussel en te Luxemburg - en een vooralsnog onbepaald aantal Tribunalen van Eerste Instantie. ${ }^{85}$ De heerlijke jurisdicties ten plattelande werden bij deze gelegenheid opgeheven. Op deze wijze werd het beginsel van rechtspraak in drie instanties - ook in strafzaken - geintroduceerd (art. 1).

Vooruitlopend op de invoering van het règlement provisionnel pour la procédure criminelle dans les Pays-Bas autrichiens, werden in de artikelen 55 68 van de ordonnantie van 3 april 1787 een aantal maatregelen getroffen, die een einde zouden moeten maken aan misstanden op het gebied van de strafrechtspleging. Met ingang van 1 mei 1787 moesten alle strafprocessen, aanhangig bij heerlijke schepenbanken, ter afdoening worden overgedragen aan Tribunalen van Eerste Instantie (art: 58). Vonnissen van Tribunalen van Eerste Instantie, inhoudende veroordeling tot lijfstraf, verbanning of gevangenisstraf, moesten ter bevestiging worden voorgelegd aan een van beide Hoven van Appel (art. 59). In geval van oplegging van de doodstraf, diende bevestiging te worden gevraagd aan het Soeverein Hof van Justitie (art.60). Bovendien werd aan gevangenen die zich in hun rechten verkort voelden door een Tribunaal van Eerste Instantie, toegestaan zich daarover bij een van beide Hoven van Appel te beklagen (art. 61). Tevens werd bij deze gelegenheid de pijnbank officieel afgeschaft (art. 63). Gratie kon worden verzocht bij het Soeverein Hof varh Justitie, hetzij rechtstreeks, hetzij door tussenkomst van een der beide Hoven van Appel (art. 68). ${ }^{86}$

Dected van 3 februan 1784 (Recueil des Ordonnances des Pays-Bas, 3 serie, dl 12, b12. 326)

\$5 Recueil des Ordonnances des Pays-Bas, 3 sefie, dl. 13, bli. 3 (edict van 1 jaruan 1787 ); blz. 24 (edict van 3 april 1787 )

Hoor eed concies overzicht van de strafrechtelije hervorimingen van Jozef II, zie: F. Stevens, La codiftcation penale en Belgique, heritage Français ef debats Neerlandais, un: X. Rousseaux, R. Lévy (ed,), Le pénal dans tous ses Etats. Justice, Eats et sociétés en Europe (XII-XX siecles), Brussel 1997 (Publications des facultés universitaires Saint-Louis, $n^{*} 74$ ), blz. 287-302, ta. a. blz. 287-290; wer de achtergronden zie: J.M. Canchies, La législation tefomatrice de Joseph ll: politique, vocabulaire, inspirations, in: R. Martinage (red.). Justice et lratitutions françases en Belgique (1795/1815), Lille, 1996 
Deze bepalingen stemden in belangrijke mate overeen met hetgeon kanselier en raden van de Soevereine Raad te Roemond sedert 1766 en met name in bet kader van de affaire Laurent Tïmmernans hadden bepleit. Het behoeft daarom geen betoog, dat deze ontwikkeling door hen met instemming werd begroet. Nadat bij ordonnantie van 20 aprill 1787 het Tribunaal wan Eerste Instanie in het hertogdom Gelre was ingesteld, hebben zij hun benoeming tot rechters in dit nieuwe college zonder bezwaren aanvaard. ${ }^{87}$

Zoals bekend zijn deze vernieuwingen onder politieke druk, voomamelijk van de Staten van Brabant, al spoedig ongedaan gemaakt, maar ongetwijfeld hebben zij de weg bereid voor de introductie van de Franse revolutionaire wetgeving, die enkele jaren later zou leiden tot een definitieve hervorming van strafrecht en strafprocesrecht, toen bij besluit van 24 frimaire an IV (26 november 1796) in de departementen van de voorheen Oostenrijkse Nederlanden de afkondiging werd gelast van Code des délits et des peines van 3 brumaire an IV (25 oktober 1795), de revolutionaire voorloper van de Code pénal van Napoleon, die her Nederlandse en Belgische strafrecht wan de negentiende eeuw op beslissende wijze heeft beïnvloed.

De vernieuwing van strafrecht en strafprocesrecht heeft ook andere Limburgse territoria niet onberoerd gelaten. In Pruisisch Opper-Gelre kan men wijzen op de hervormingen die in 1783 en volgende jaren op last van de groot-kanselier Von Carmer werden voorgesteld. Deze voorstellen betroffen o.a. professionalisering van de schepenrechtsprak in de heerlijkheden ten plattelande en de instelling van een Criminal Richter te Geldern, aan wie de jurisdictieheren voortaan op vrijwillige basis de berechting van ernstige misdrijven zouden kunnen toevertrouwen, die anders onder de competentie van de schepenbanken zouden vallen. Deze voorstellen resulteerden uiteindelijk in het Reglement wegens de inrigting wan het justitie weezen bij de ondergerichen in Zijne Koninklijke Majesteits Aandeet in het Hertogdom Gelder van 21 juni 1786. In het hertogdom Gulik was de keurvorst Karl Theodor van Beieren de motor achter de humanisering van het strafrecht. Ook hier ziet men professionalisering van de rechtspraak, instelling van het Jülichs-Bergische Appellationsgerichtshof te Düsseldorf (1769), afschaffing van de tortuur (1776) en de introductie van gevangenisstraffen en de daartoe benodigde penitentiaire

37. GA Roermond, Oudarchief Roermond, inw.n. 340, nr. 581

Th.J. van Rensch. Het Hof van Justitie van Pruisisch Gelire. Enkele aspecten van zijn geschiedenis, competentie en de invloed van de achtiende-eeu wse rechtsont wikkeling in Pruisen, in: PSHAL 113 (1977) blz. 193-268, 4.a.p. blz. 246-260 
inrichtingen. In het geestelijk vorstendom Thorn werden overeenkomstige initiatieven genomen door de vorstin-abdis Maria Cunegonda van Saksen. Hier lag het accent eveneens op hervorming van de rechterlijke organisatie, c.q. atschaffing van de schepenrechtspraak, codificatie en verplichte toetsing van vonnissen in strafzaken door het Hof van Appel. ${ }^{90}$

De strafrechtelijke hervorming in deze territoria vertoont mi. gemeenschappelijke trekken. Het betreft in alle gevallen vernieuwing van bovenaf, in opdracht van verlicht absolutistische vorsten, waarbij het accent wordt gelegd op vernieuwing van de rechterlijke organisatie, professionalisering van de rechtspraak, introductie van meerdere instanties, afschaffing of beperking van tortuur en lijfstraf en introductie van gevangenisstrat.

Een alternatteve vorm van vernieuwing vindt men in het graatschap Loon en het daaraan gelieerde graafschap Horn, waar men de risico's van de nietprofessionele schepenrechtspraak vanouds heeft willen beperken door alle (tussen-)vounissen in strafzaken te onderwerpen aan verplichte rencharge of hoofdvatart. Hier werd in 1752 een nieuwe stijl van procederen in criminele zaken vitgevaardigd, die in negen hoofdstukken en veertien bijlagen, de plattelandsschepenen als het ware stap voor stap door het strafproces leidde en aldus de bezwaren van de niet-professionele rechtspraak poogde te ondervangen. ${ }^{9 !}$

In de Statse Landen van Overnaze en in Stats Opper-Gelder ging het initiatief tot vernieuwing van het strafrecht naar het zich laat aanzien uit van magistraten. De procureur-generaal van de Staatse Raad van Brabant, Joannes

P. Robent, Die Strafrechtspllege am Hapt und Kriminalgencht za Julich von der Karolina bis zur Aufkthrung (1540.1744). Rin Beirag zur Rechtsgeschichte des Niedertheins. Julich 1987; unverinderte Nachdruck der Ausgabe 1943 (Veroffent-

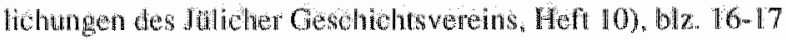

w. A.J.A. Berkvens. Het Neuwe 1.andrecht wan Thom. Verlicht absolutisine en codilicatie onder het bewind van de vortin abdis Maria Cunegonda van saksen (17761794), In: E.C.C. Coppens (ed.), Honoris Causa Opstellen angeboden aan prof mr. O. Mooman van Kappen, Nijmegen 1999, blz. 1-28; A.M.J.A. Berkvens, Hel concept van de "Nicuwe Landrechten van het Hooggrafelijk Stifl en Vorkiendom Thom" in: Verslugen en Mededelingen OVR, nieuwe reeks d1. 9 (1997), blz. 39-97.

" Cfr, L. Polain, Recueill des Ordonnances de la Principante de Liege 3 e serrie 1684 1794. vol. 2. le purtie Bruxelles 1860, pp. $219-238$ (Franstalige tekst); woor de Nedeflandstalige versie zie: M.G. de Lowvrex, Recueil contenant les edits et reglemens fuits pour le Pats de Liege er comte de Looz ... deel IV, Luik 1752, supplement blz. 2 . 50. 
Fredericus van Steelant ${ }^{92}$ en de luitenant-voogd van het land van Valkenburg, Adriaan Lodewijk Pélerin ${ }^{93}$ stelden misstanden in de criminele rechtspleging in de Staatse landen van Overmaze aan de kaak en deden voorstellen tot redres. In Staats Opper-Gelre ging het initiatief uit van de eerste presiderende en andere raden van het Staats Hof te Venlo, die vanaf 1762 met een zekere regelmaat aandacht vroegen voor misstanden op het gebied van de criminele rechtspleging met name in het ambt Montfort. Hun woorstellen tot het invoeren van professionalisering van de rechtspraak en approbatie van criminele vonnissen door het Staats Hof te Venlo werden door de Staten-Generaal der Verenigde Nederlanden niet overgenomen, waarschijnlijk wegens verzet van de Nassause Domeinraad, die de belangen van de erfstadhouder Willem $V$ effectief behartigde. ${ }^{94}$ In hoeverre tweeherig Maastricht was aangeraakt door het strafrechtelijk verlichtingswirus is vooralsnog een open vraag. De bijzonder rijke rechterlijke archieven van Maastricht zijn nog altijd voor wetenschappelijk onderzoek vrijwel ontoegankelijk. Op basis van de adviezen van de Maastrichtse raadspensionaris Adriaan Lodewijk Pélerin mag men echter aannemen, dat zich ook hier vanaf \pm 1780 een omslag in het strafrechtelijk klimaat heeft voorgedaan. ${ }^{9.5}$

J. J.M.M. wan Hall Een onderzoek nar de rechtsphak in de Staatse Landen van Overmaze door de advocaat-fiscaal J.F. wan Steelant in 1772, in: A.M.I.A. Berkvens, A.FI. Gehlen en G.H.A. Vonner (red.). Ten Werentliken Rechte. Opsiletlen over Limburgse Rechtsgeschiedenis, Masstricht 1990, blz. 59-86

9. A.L. Pélerin 1738-1804; lic. rechen Leiden, werd in sept. 1775 benoend tot luitenant-woogd van het Land wan Valkenburg. Hij cumuleerde dere functie met die van pensionaris van Mastricht sedert jan. 1776. Cr. C.D. Franquinet, Notice biographique d' Adrien Louis Pelerin, in: Annales de la Société historique et archéologique à Maestricht 1 (1854-1855) bla. 1-6.

RAL, Hof van Venlo, inv.ne. 1080

95 RAL. Collectie Handschriften, inv nT. 26" Memoriên en advisen, gemaakt en gegeven door mij Adr. Lod. Pelerin" , nrs. 20, 25, 45,53,54,58, 59, met dank aan de heer A.G. Siroom 
Mijnheer de Rector Magnificus,

\section{Zeer Geache Toehoorders}

Het object van de rechisgeschiedenis van de Limburgse Territoria kan men omsehrijuen als de bestudering van de rechtsstelsels van de territoria, waaruit de huidige Nederlandse provincie Limburg zich heeft gevormd. Deze territoria makten veelal deel uit van grotere staatkundige entiteiten, waarvan het bestuurlijk zwaartepunt buiten de grenzen van de huidige provincie lag. Voor de beofenatar van de rechtsgeschiedenis der Limburgse territoria betekent dit, tat hij zich zal moeten verdiepen in de rechtsgeschiedenis van de Zuidelijke Nederlanden en van het prinsbisdom Luik, die van de Republiek der Verenigde Nederlanden, alsmede de Duitse rechtsgeschiedenis, met name ook van Pruisen en Oostenrijk. Het is juist de beinnwoeding door "vreemde" rechtsstelsels die de rechtsgeschiedenis der Limburgse territoria zijn bijzondere charme verleent. Bij de beofening van de Limburgse rechtsgeschiedenis heeft men traditioneel veel aandacht besteed an de bestudering van normatieve bromnen. De afgelopen jaren is geleidelijk het accent verlegd naar de bestudering van de rechtspraktijk. Dankzij de inspanningen van Limburgse archivarissen - en met name van Dr. Gerard Venner - zijn inmiddels tal van rechterlijke archieven, waaronder de archieven van het Hoofdgerecht Roermond en die van het Staats Hof van Venlo voor wetenschappelijk onderzoek toegankelijk geworden. Andere zijn inmiddlels in bewerking genomen, zoals het archief van de Soevereine Raad te Roermond en de rechterlijke archieven van Maastricht. In de komende jaren hoop ik in goede samenwerking met de Limburgse archivarissen nieuwe initiatieven te ontwikkelen om de jurisprudentie van de gewestelijke justitiehoven, de Maastrichtse commissarissen-deciseurs en van de beide Maastrichtse hooggerechten verder te bestuderen.

Mine heren wan her College wan Bestur, Van harte dank ik $U$ voor het in mij gestelde vertrouwen. Wees ervan overtuigd, dat ik naar best vermogen unhoud en gestalte zal helpen geven aan het concept van de lerende regio.

Mijne heren, Leden vin de Commissie van roezicht,

Geach bestuur van Limburgs Gesched- en Oudheidkundig Genootschap,

$\mathrm{lk}$ ben $\mathrm{U}$ bijzonder erkentelijk voor mijn benoeming tot bijzonder hoogleraar rechtsgeschiedenis der Limburgse Territoria. Van harte ondersteun ik uw streven om tezamen net het Sociaal Historisch Centrum voor Limburg over te 
gaan tot oprichting van een Limburgs Historisch centrum als expertise-centum voor professionele en amateuristische geschiedbeoefening in Limburg. Mh ben ervan owertuigd, dat een dergelijk institutu neuwe impulsen zal geven ande regionale geschiedbeoefening, waaran Limburgs Geschied-en Oudheidkundig Genootschap reeds 135 jaar zijn beste krachten wijd.

Hooggeleerde Spruit, Beste Jop. In de pioniersjaren van de Faculteit der Rechtsgeleerdheid hebben wij ons gezamenlik ingespannen om de rechtsgeschiedenis een "honorabele" plaats te geven in het curriculum. Deze inspanningen zijn niet tevergeefs geweest. Rechtsgeschiedenis is thans hecht verankerd in het onderwisprogrammu. Het verhengt mij daarom bijzonder, dat de Ius Commune-onderzoeksschool, waarin Maastricht, Utrecht en Leuven participeren, ons nieuwe mogelijkheden tot samenwerking biedt.

\section{Hooggeleerde Moorman van Kappen, Beste Olaw,}

Uw immer aanstekelijke geestdrift voor de rechtsgeschiedenis en uw altijd opbouwende kritiek zijn voor mij een permanente bron van inspiratie. Voor mijn vorming en opleiding ben ik $U$ zeer veel dank verschuldigd. Zeer wel ben ik mij ervan bewust, dat Uw bereidheid mij als onderzoeker een kans te geven, mij heeft gebracht naar de plaats, vanwaar ik U vandeag mag toespreken.

\section{Hooggeleerde Gehlen, Beste Ton,}

De afgelopen tien jaren hebben wij met veel plezier getuinierd in de lusthof van de Rechtsgeschiedenis der Limburgse Territoria. Ik ben er trots op als jouw opvolger thans deze leerstoel te mogen bekleden, maar bovenal ben ik blij, dat je sedent je emeritat nog meer wjd hebt gevonden voor de beofening van de rechtsgeschiedenis. Ik verheug me bujzonder op onze voorthrunde samenwerking in het kader van Hoger Onderwijs voor Ouderen.

\section{Beste Rentio en Tanja,}

Beste Collegae van de capaciteitsgroep Metajuridica en van de Juridische Fachlter.

Sedert dertien jaar koester ik mij in de warmte van jullie collegialiteit en vriendschap. IK verheug mij op onze verdere samenwerking.

Lieve Anne-Marie, Catheline en Wierc.

Julle zijn het beste deel van mijn leven. Daaron arag ik deze rede an jullie op. 